\title{
Parent Material Influence on Soil Response to Vegetation Change, Southeastern
}

Minnesota, U.S.A.

\author{
Joseph A. Mason ${ }^{1 *}$, Peter M. Jacobs ${ }^{2}$, Kristine E. Gruley ${ }^{1}$, Paul Reyerson ${ }^{3}$, and Paul R. Hanson ${ }^{4}$
}

1. Department of Geography, University of Wisonsin-Madison, 2. Department of Geography and Geology, University of Wisconsin-Whitewater, 3. Department of Geography and Earth Science, University of WisconsinLaCrosse, 4. School of Natural Resources, University of Nebraska-Lincoln.

*Corresponding author, Email: mason@geography.wisc.edu

\section{ABSTRACT}

Soil morphology changes dramatically across the former transition from forest to grassland in the Midwestern U.S.A. That vegetation boundary shifted as a result of Holocene climatic change and fire suppression following Euroamerican settlement, but the timescale of soil response to those vegetation changes and the factors that influence it are poorly known. On steep colluvial slopes of southeastern Minnesota, Mollisols with thick, dark A horizons typically associated with grassland are found today under deciduous forest. Soils with much thinner and/or lighter-colored A horizons occur immediately up- and downslope of the forest-covered Mollisols. Most of the soils with thick A horizons are not in topographic settings found to favor organic matter accumulation in other landscapes. Principal components analysis highlights important axes of textural and mineralogical variation among horizons of these soils, often related to parent material properties. Soils with and without thick A horizons are separated along one principal component heavily loaded by high $\mathrm{pH}$, reflecting the presence of dolomite fragments in the hillslope sediment that soils with thick, dark A horizons formed in. Stable C isotope analysis reveals that the Mollisols with thick, dark A horizons under forest had $\mathrm{C}$ input from vegetation 
25 with abundant $\mathrm{C}_{4}$ grasses in the past. Public land survey data also indicate replacement of 26 grassland or savanna by forest since 1854 on colluvial slopes where forest-covered Mollisols

27 occur today. We propose that the soils with thick, dark A horizons under forest today reflect a 28 lagged response to vegetation change, from grassland or savanna to closed forest. Their thick A

29 horizons and some $\mathrm{C}_{4}$-derived organic matter may be preserved because dolomite weathering 30 releases abundant $\mathrm{Ca}^{++}$and $\mathrm{Mg}^{++}$that favor aggregation and organic matter stabilization. Soils

31 with thin A horizons just up- or downslope may also have formed partly under grasses, but have

32 responded more quickly and/or more substantially to vegetation change.

33 KEYWORDS: Soil response to vegetation change, $\mathrm{C}$ isotopes, Mollisols, Alfisols, parent 34 material

\section{1. Introduction}

Major changes in soil morphology associated with the midlatitude forest to grassland transition were recognized early in the history of pedology, most notably in the work of Dokuchaev (1883). There is also a history of hypotheses on relict soil characteristics related to geologically recent shifts in the location of the forest-grassland boundary (Bronger, 1991; Miedema et al., 1999; Neustruev, 1927). In the Midwestern USA prior to the nineteenth century expansion of agriculture, there was a generally westward transition from deciduous forest to tallgrass prairie, with an intermediate zone of savanna or open woodlands (Fig. 1a). The complex 44 spatial pattern of this vegetation boundary was recorded in detail by nineteenth century public 45 land surveys and has been attributed to effects of both climate and wildfire, with discussion of 46 the relative role of each factor continuing up to the present (Curtis, 1959; Grimm, 1984; Nelson 47 and $\mathrm{Hu}, 2008$; Shuman et al., 2009). Across this forest-prairie ecotone, there is a corresponding 
48 transition from Alfisols to Mollisols (generally from Luvisols to Chernozems or Phaeozems in 49 the WRB classification). Studies in Minnesota, Iowa, and Illinois have documented marked 50 changes in soil morphology over a distance of a few tens of kilometers or less, with thinner A

51 horizons and more distinct textural contrasts between A or E and B horizons on the forest side of 52 the boundary (Bailey et al., 1964; Mason and Nater, 1994; Severson and Arneman, 1973; White 53 and Riecken, 1955).

54 The fact that these morphological changes occur at, or close to, the nineteenth century 55 vegetation boundary is especially noteworthy because paleoecological research has demonstrated 56 that the forest-prairie boundary has shifted substantially over the past 10,000 yr (Webb et al., 57 1983; Williams et al., 2009). In fact, even where forest expanded into prairie within the last 58 millennium, Alfisols sometimes dominate the landscape recently occupied by forest (Grimm, 59 1983; Umbanhowar, 2004). Thus, it appears that under the right circumstances, soil morphology 60 can change rapidly in response to the transition from prairie to forest.

On the other hand, some Mollisols near the forest-prairie boundary in Minnesota are forest62 covered today, or were at the time of nineteenth-century land surveys (Almendinger, 1990; Buell 63 and Cantlon, 1951; Grimm, 1983). One obvious explanation for these anomalous soils is that 64 they have not had enough time to respond to recent advance of forest into prairie (e.g. Geis et al., 65 1970). This raises the question of whether response time to vegetation change could be longer for 66 soils in certain geomorphic settings or parent materials. In many landscapes, A horizon 67 thickness and whole-profile organic carbon (OC) content are greater on gentle and concave 68 lower slopes than on steep and convex upper slopes. This pattern is attributed to downslope 69 translocation of OC-rich soil, greater plant productivity and OC addition to soils, and/or 70 conditions that reduce decomposition rates on lower slopes that are often depositional settings 
71 (Aandahl, 1948; Berhe et al., 2008, 2012; Doetterl et al., 2012; Gessler et al., 2000; Schimel et

72 al., 1985; Yoo et al., 2006). Thus, some geomorphic settings might allow longer-term

73 persistence of thick OC-rich A horizons after forest invasion of prairie, or could even allow

74 development of such horizons entirely under forest. Alternatively, soils with thick, dark A

75 horizons may form entirely under forest in carbonate-rich parent materials, because continual

76 release of abundant $\mathrm{Ca}^{++}$and $\mathrm{Mg}^{++}$from weathering carbonates favors OC accumulation. This

77 has generally been the interpretation of rendzina soils on chalk and other carbonate rocks

78 (Kubiena, 1953, p. 179; Schreier and Lavkulich, 1985; Ugolini and Tedrow, 1963), and has been

79 invoked as at least a partial explanation for other examples of thick OC-rich A horizon formation

80 under forest (Anderson et al., 1975a; Anderson et al., 1975b; Schaetzl, 1991). The mechanism

81 responsible probably involves $\mathrm{Ca}^{++}$and $\mathrm{Mg}^{++}$acting as "bridges" that allow OC sorption on

82 mineral surfaces, an important mechanism of OC stabilization (Oades, 1988; Mikutta et al.,

83 2007; von Lützow et al., 2006, 2008).

84 The questions raised by soil patterns near the forest-prairie border have clear implications for

85 the broader issue of soil organic carbon (OC) storage and how it is affected by natural or

86 anthropogenic environmental change. Where forest replaced prairie in the Midwest, rapid

87 transformation of Mollisols with thick, OC-rich A horizons into Alfisols could have quickly

88 produced an overall reduction in OC storage at the landscape scale. The rate and spatial pattern

89 of this response might have been substantially affected by topographic setting and parent

90 material, however.

91 This paper reports results from a study of soils on steep bedrock-controlled hillslopes in

92 southeastern Minnesota, U.S.A. (Fig. 1b), which include Mollisols with thick, OC-rich A

93 horizons under mature deciduous forest. These A horizons may be relict features, formed under 
94 prairie that has now been replaced by forest. This interpretation is supported by the presence of

95 similar A horizons under small patches of prairie on similar parent materials nearby, and by

96 reconstructions of regional vegetation history. Across the Midwestern U.S.A., prairie spread

97 eastward in the early or middle Holocene, followed by westward readvance of forest in the late

98 Holocene (Baker et al., 1992; Webb et al., 1983). Plant macrofossil, pollen, and OC isotopic

99 data from stream sediments near the study area indicate expansion of prairie between about 6500

100 and 3500 cal yr B.P., with a subsequent shift back to greater forest cover (Baker et al., 2002;

101 Chumbley et al., 1990). It is unlikely that either forest or prairie ever completely covered the

102 study area, however, because its relatively rugged topography created local settings with widely

103 varying microclimates and susceptibility to wildfire. In parts of Minnesota just north of our study

104 area, there is evidence that some of the expansion of deciduous forest took place within the past

105 millennium or even the last several hundred years (Grimm, 1983; Shuman et al., 2009;

106 Umbanhowar, 2004). By the nineteenth century, the landscape of the study area was a mosaic of

107 forest, prairie, and savanna (Marschner, 1974).

108 While these reconstructions of past vegetation change clearly suggest that the soils with

109 thick, dark A horizons under forest are relicts of former prairie, this interpretation is complicated

110 by other observations. These Mollisols are not distributed across the entire catena on the

111 hillslopes in our study area, but instead occur on specific slope segments. Alfisols or Inceptisols

112 with much thinner A horizons occur both uphill and downhill from the Mollisols, on the same

113 slopes, and on ridgetops. Many of the Alfisols have distinct E horizons and strong textural

114 contrast between E and underlying Bt horizons. It seems unlikely that prairie would occupy only

115 certain segments of these slopes. In addition, the thickest and darkest A horizons under forest

116 are generally close to dolomite outcrops, with abundant dolomite fragments in part or all of the 
117 profile. This observation raises the possibility that a carbonate-rich parent material can entirely 118 explain the genesis of those distinctive A horizons, as described above for rendzinas and similar 119 soils in other regions, and they did not develop under grassland vegetation at all. In addition, the 120 soils are formed in hillslope sediments made up of various mixtures of Late Pleistocene loess and 121 bedrock-derived materials. The relative proportion of loess could potentially have affected OC 122 accumulation and turnover, given the distinctive silt-rich texture, high moisture retention 123 capacity, and smectitic clay mineralogy of the loess (Jacobs et al., 2011; Jacobs et al., 2012). 124 We studied whether distinctive parent material or topographic setting could have favored the 125 occurrence of thick, dark A horizons under forest, and then used stable C isotope analysis of soil 126 organic matter to detect any past influence of prairie vegetation. Warm-season grasses that are 127 abundant in the tallgrass prairie of southeastern Minnesota (Minnesota DNR, 2005), including 128 remnant patches within the study area, all use the $\mathrm{C}_{4}$ photosynthetic pathway (Sage et al., 2011; 129 Teeri and Stowe, 1976). In contrast, trees and forest understory species in this setting 130 exclusively use the $\mathrm{C}_{3}$ pathway. The two pathways involve different degrees of discrimination 131 against the heavy isotope ${ }^{13} \mathrm{C}(\mathrm{O}$ 'Leary, 1988) and as a result, organic matter added to soils from $132 \mathrm{C}_{4}$ and $\mathrm{C}_{3}$ plants has quite different isotopic composition (Boutton, 1996; Cerling et al., 1989). 133 Thus, where prairie was replaced by forest, its past presence can potentially be detected in soil 134 OC (e.g. Wang et al., 1993), especially in deeper horizons where OC turnover time is hundreds 135 to thousands of years (Wang et al., 1996). We also obtained data on stable $\mathrm{N}$ isotope ratios, 136 which can help interpret depth trends of $\mathrm{C}$ isotopes as effects of vegetation change or other 137 processes.

\section{Materials and Methods}


The study area is a bedrock-controlled, highly dissected landscape in Houston County, southeastern Minnesota, U.S.A. (Fig. 1b). This region was glaciated in the Pliocene or Early to

145 Middle Pleistocene (Hobbs and Goebel, 1982), but glacial sediments have largely been removed 146 by subsequent erosion and the landscape has been dissected by streams, producing deep valleys 147 with local relief of 100 to $150 \mathrm{~m} \mathrm{~km}^{-2}$. Valley-margin slopes often have segments steeper than $14835^{\circ}$. The climate is humid and continental, with a mean annual temperature of $6.7^{\circ} \mathrm{C}$ and mean annual precipitation of $889 \mathrm{~mm} \mathrm{yr}^{-1}$ (1971-2000 means for Caledonia, Minnesota).

We focused on the genesis of Mollisols and other soils on steep valley-margin slopes. The 151 soils on gently sloping ridgetops and valley floors of the study area have distinctly different 152 parent materials and present-day land use (largely agricultural fields) and are beyond the scope 153 of this paper. Throughout the study area, steep slopes similar to the ones we sampled are covered 154 almost entirely by natural vegetation, predominantly deciduous forest but also including patches 155 of prairie on south-facing slopes.

Soils on these steep slopes formed in a mixture of Late Pleistocene loess and hillslope 157 sediments derived from local Paleozoic bedrock (Fig. 2). The Oneota Dolomite (Ordovician) 158 forms a resistant caprock that weathers into angular boulders, which are distributed downslope, 159 often mantling the uppermost part of the underlying Jordan Sandstone (Cambrian). Figure 2 also 160 illustrates typical surficial material stratigraphy in the study area, based on extensive prior 161 research (Lively et al., 1987; Mason, 1995; Mason and Knox, 1997; Mason et al., 1994). Late 162 Pleistocene Peoria Loess was deposited across the study area, and is preserved in thicknesses up 
163 to $4 \mathrm{~m}$ on wide ridgetops (Mason et al., 1994). Unweathered Peoria Loess is predominantly fine

164 to medium silt with $10-20 \%$ clay and contains some detrital dolomite and calcite (Mason, 1992;

165 Mason and Nater, 1994). Peoria Loess thins greatly toward steep valley-side slopes we sampled.

166 At the upper end of those slopes surface soils formed in thin loess and the underlying reddish

167 brown, clay-rich material, probably a mixture of bedrock residuum and weathered older loess

168 (Frolking et al., 1983; Jacobs et al., 1997).

169 Farther downslope, the only loess preserved is mixed with bedrock-derived material in a

170 predictable sequence of hillslope deposits (Fig. 2), summarized here using three lithofacies

171 defined by Mason (1995). Steep slopes above and just below the dolomite-sandstone contact are

172 mantled by a clast-supported diamicton $(D c)$ with a silt loam to sandy loam matrix, from 0.5 to

173 about 2 m thick. Almost all clasts are angular fragments of Oneota Dolomite derived from a

174 short distance upslope. Downslope from the area mantled by the Dc lithofacies, there is a

175 somewhat gentler slope segment with scattered sandstone outcrops and a relatively thin mantle

176 of massive sand $(\mathrm{Sm})$ containing only scattered dolomite fragments. As the gradient decreases

177 across the upper boundary of a prominent concave footslope, the sandy sediment of Sm overlies

178 massive silt-rich deposits $(F m)$, which resemble Peoria Loess but contain substantially more sand

179 and occasional rock fragments.

180 All three lithofacies accumulated primarily in the Late Pleistocene when a periglacial climate 181 limited vegetation cover and produced widespread permafrost (Mason and Knox, 1997). At that

182 time, Peoria Loess was rapidly eroded from slopes and narrow ridgetops and reworked onto

183 footslopes to form the Fm lithofacies. The Dc lithofacies includes abundant debris produced by

184 accelerated frost-weathering of dolomite bedrock, mixed with loess and bedrock-derived sand

185 and moved downslope by frost creep. The Sm lithofacies is weathered sandstone moved 
186 downslope by slopewash and bioturbation. Some downslope movement of soil by bioturbation, 187 frost creep, and rainsplash has undoubtedly continued through the Holocene, but at low rates.

188 The general distribution of Mollisols and other soils on steep bedrock slopes of our study 189 area is evident in the Houston County soil survey (Lueth, 1984). Mollisols with thick, dark A 190 horizons and weakly developed Bw horizons are mapped on steep upper slopes (Fig. 3). These

191 include Brodale soils (Entic Hapludolls), often under small patches of prairie on south- or 192 southwest-facing slopes, and more extensive Lacrescent soils (Typic Hapludolls) under 193 deciduous forest on all slope aspects. These soils formed mainly in the Dc lithofacies, based on 194 typical profile descriptions. Soils mapped up- and downslope from and these Mollisols are 195 mostly Alfisols (Typic and Glossic Hapludalfs), with patches of Entisols (Udipsamments or 196 Quartzipsamments) in the sandy Sm lithofacies.

\subsection{Site Selection and Field Sampling}

This paper is based on 29 soil profiles, 26 of which were studied at four hillslope sites, on 201 slopes with northeast (CAR), northwest (RN, RH), and southwest (SF) aspects (Fig. 1b, Fig. 4).

202 Three other soils were sampled on ridgetops mantled with thick loess (Fig. 1b), to compare 203 pedogenesis in that setting with the hillslope soils that were the primary focus. Field descriptions 204 and all laboratory data are provided in supplemental online tables S1-S3.

205 We selected the hillslope sites because a) reconnaissance suggested that they represent 206 downslope sequences of soils similar to those that were mapped over many of the slopes in the 207 study area by Lueth (1984), b) three sites include forest-covered Mollisols and the fourth 208 represents Mollisols under a prairie patch on a southwest-facing slope for comparison, and c) at 
each site there were fresh exposures of soils along hundreds of meters of trails cut into the hillsides for logging or all-terrain vehicle use. These exposures often reached weathered bedrock, and while they were not aligned along the direction of steepest descent, they provided an outstanding opportunity to examine soil variation from the shoulder slope down to the upper footslope (from A to A' in Fig. 2). Based on reconnaissance of the exposures, we selected profiles for detailed study (nine profiles at CAR, six each at SF and RH, and five at RN, see Fig. 4). At all sites, sampled profiles were distributed across the elevation range of soils with relatively thick, dark A horizons at each site, and at the sites where exposures allowed this (CAR, RN, RH), we also sampled soils with thinner A horizons lower and/or higher on the slope. Within the band of thicker A horizons, profiles were selected to represent the overall range of variability of A horizon thickness and B horizon morphology that we observed in the continuous exposures. At the CAR site we also supplemented exposures with a profile sampled to bedrock at $1.2 \mathrm{~m}$ depth on the lower slope using a 2.5-cm diameter core (CAR-9), and a hand-dug pit on the opposite side of the ridge from the other profiles (CAR-12).

None of the sampled soils at these four hillslope sites have been cultivated. The SF site is located on a small patch of prairie, similar to many others on steep southwest- or south-facing slopes in the surrounding region (Curtis, 1959; Minnesota DNR, 2005). Vegetation at the SF site is dominated by warm-season $\mathrm{C}_{4}$ grasses, including little bluestem (Schizachyrium scoparium), big bluestem (Andropogon gerardii), Indiangrass (Sorghastrum nutans), and sideoats grama (Bouteloua curtipendula). Scattered small trees, mostly eastern red cedar (Juniperus virginiana) are also present. At the CAR site, CAR-12 is in a similar but much smaller patch of prairie grasses, while the rest of that site and all of the RN and RH sites are covered with deciduous forest, including trees with diameters $>40 \mathrm{~cm}$. Larger trees are predominantly red oak (Quercus 
232 rubra) and white oak (Q. alba), with smaller numbers of bur oak (Q. macrocarpa). Smaller trees

233 and saplings include the same three oak species, American elm (Ulmus americana), shagbark

234 hickory (Carya ovata), sugar maple (Acer saccharum), basswood (Tilia americana), and black

235 cherry (Prunus serotina). Groundcover plants at all sites are those common in oak forests of

236 southern Minnesota (Minnesota DNR, 2005), with few invasive species, suggesting that these

237 sites do not have unusual soil conditions or disturbance history.

238 The three ridgetop soils formed in loess $\geq 1 \mathrm{~m}$ thick, and were described and sampled from

239 2.5-cm diameter cores at two sites (CAR-South and VR) and from a pit at one (AL). All three

240 soils are in remnant patches of mature deciduous forest. The CAR-S profile is on the loess-

241 mantled ridgetop closest to the CAR hillslope site.

$242 \quad$ Freshly exposed faces were created by digging back from the existing trail cuts, and soil

243 morphology was then described in the field using standard methods (Schoeneberger et al., 2002).

244 Content of rock fragments $>2 \mathrm{~mm}$ was estimated visually during profile description, based on

245 previous quantitative measurements of Dc lithofacies rock fragment content (Mason, 1995).

246 Samples for most laboratory analyses were collected from the entire thickness of horizons $<25$

247 cm thick; thicker horizons were subdivided for sampling. Small samples for C isotope analysis

248 or radiocarbon dating were collected from selected profiles at the CAR site, from freshly

249 exposed faces.

250

251 2.3. Laboratory Methods

252

253 Bulk samples were air-dried, ground, and sieved at $2 \mathrm{~mm}$ for all laboratory procedures.

254 Laboratory analyses were carried out on subsets of 28 soils (OC and pH), 24 soils (particle size 
analysis), 18 soils (clay mineralogy) and 14 soils ( $\mathrm{C}$ and $\mathrm{N}$ isotopic analysis); the subsets used are listed by site in Table 1 and were intended to represent the range of observed morphological variation. We measured $\mathrm{pH}$ in 1:1 soil:water suspensions. Loss on ignition (LOI) at $360^{\circ} \mathrm{C}$ for 2 hr was used to estimate OC content (Konen et al., 2002, MLRA 108 equation), in part because this method does not require pretreatment for carbonate removal. We measured clay $(<2 \mu \mathrm{m})$, silt (2-63 $\mu \mathrm{m})$, and sand (> $63 \mu \mathrm{m})$ by the pipette-sieve method (Gee and Bauder, 1986). Darkcolored A horizon samples were pretreated with $30 \% \mathrm{H}_{2} \mathrm{O}_{2}$ at $70-90^{\circ} \mathrm{C}$. Carbonate minerals were not removed because detrital dolomite grains form a substantial fraction of the sand and silt in some samples and secondary carbonate cementation is rare and quite weak.

Samples used for analysis of clay mineralogy were dispersed with $0.5 \mathrm{mg} \mathrm{L}^{-1} \mathrm{Na}-$ metaphosphate, and clay $(<2 \mu \mathrm{m})$ was separated by settling. Clay mineralogy was determined by $\mathrm{x}$-ray diffraction of clay smears on glass slides using $\mathrm{Cu}-\mathrm{k} \alpha$ radiation, with a scan speed of $2^{\circ}$ per minute and a step of $0.02^{\circ}$, in a Rigaku Miniflex diffractometer. Clay samples were saturated with $\mathrm{Mg}^{2+}$ followed by ethylene glycol solvation (Moore and Reynolds, 1989). Height above background for the 001 peak of each major clay mineral was determined using JADE software (Materials Data Inc.), and clay mineral percentages were estimated from relative peak heights following a method of the Illinois State Geological Survey (Method I of Hughes and Warren, 1989). All clay associated with a $1.4 \mathrm{~nm}$ peak was counted as vermiculite, though it may also include hydroxy-interlayered smectite and/or hydroxy-interlayered vermiculite.

Soil used for OC and $\mathrm{N}$ isotope analysis was subsampled in the lab, from either larger samples collected specifically for this purpose or the dried and crushed large bulk samples used for other lab analyses. In either case, roots or other macroscopic organics were removed from subsamples under a dissecting microscope, and the remaining soil was weighed into silver 
278 capsules. Only five of the 55 samples used for OC isotope analysis contained carbonates

279 detectable with $10 \% \mathrm{HCl}$ in the fine earth fraction (all from the SF site), but many others came

280 from horizons containing large dolomite coarse fragments, though with a noneffervescent matrix.

281 Therefore, all samples were treated to remove carbonates by exposing them to $\mathrm{HCl}$ fumes in a

282 desiccator for $8 \mathrm{hr}$ (Harris et al., 2001). After carbonate removal, the samples were submitted to

283 the UC-Davis Stable Isotope Facility (SIF), for analysis of C and N isotopes. Analysis at that

284 laboratory used a PDZ Europa ANCA-GSL elemental analyzer interfaced with a PDZ Europa

285 20-20 isotope ratio mass spectrometer, correcting the measured values using standards

286 interspersed within each sample batch. Results are reported as $\delta^{13} \mathrm{C}$ (the standardized ratio of ${ }^{13} \mathrm{C}$

287 to ${ }^{12} \mathrm{C}$, using the V-PDB standard), $\delta^{15} \mathrm{~N}$ (the standardized ratio of ${ }^{15} \mathrm{~N}$ to ${ }^{14} \mathrm{~N}$, using the Air

288 standard), and mass of $\mathrm{C}$ and $\mathrm{N}$ in each sample, from which we calculated C: $\mathrm{N}$ ratios. The UC-

289 Davis SIF reports that long-term standard deviations of $\delta^{13} \mathrm{C}$ and $\delta^{15} \mathrm{~N}$ measurements are $0.2 \%$

290 and $0.3 \%$, respectively.

291 Because of concerns about complete carbonate removal using $8 \mathrm{hr}$ acid fumigation, and

292 variable effects of acid treatments in general (Brodie et al., 2011; Ramnarine et al., 2011), we

293 removed carbonates from 33 replicate subsamples by immersing them in $2 \mathrm{M} \mathrm{H}_{2} \mathrm{SO}_{4}$ for $48 \mathrm{hr}$,

294 then rinsing repeatedly to $\mathrm{pH}>5$ and drying, before isotopic analysis by the same methods at

295 UC-Davis SIF. For the 33 pairs of replicate samples treated by both carbonate removal methods,

$296 \delta^{13} \mathrm{C}$ values were highly correlated $\left(\mathrm{R}^{2}=0.98, \delta^{13} \mathrm{C}(\right.$ fumigated $)=0.98 \delta^{13} \mathrm{C}$ (acid immersed) -

297 0.75). The small negative intercept is in the opposite direction of that expected for incomplete

298 carbonate dissolution with fumigation, and may reflect preferential loss of ${ }^{13} \mathrm{C}$ in $\mathrm{OC}$ that

299 dissolves during acid immersion. Overall, though, the small differences between results for most

300 samples indicate that observed patterns of $\delta^{13} \mathrm{C}$ variation within and between profiles are not 
301 substantially affected by the method of carbonate removal. The C:N ratios calculated from UC-

302 Davis SIF measurements are all in the range expected for soil organic matter, with no

303 anomalously high values suggesting residual carbonates.

304 Samples of bulk soil, collected for radiocarbon dating from three depths in one profile (CAR-

305 7), were subsampled under the microscope to avoid roots or other macroscopic organics, then

306 submitted to NOSAMS (Woods Hole Oceanographic Institute) for accelerator mass spectrometer

307 dating (carbonates were removed at NOSAMS using their standard methods).

\subsection{GIS methods}

Relationships between topography and soil morphology at the study sites and in the

312 surrounding region were characterized using a digital elevation model with 3-m cell size,

313 produced by the Minnesota Department of Natural Resources from LiDAR data. Slope gradient, 314 profile curvature (land surface curvature along the line of steepest descent), and plan curvature 315 (equivalent to curvature of contours) were calculated at the original 3-m resolution using 316 standard tools in ArcGIS v. 10.1. We then smoothed these data, using the average values of cells 317 within a 4-cell (12 $\mathrm{m}$ ) radius, to remove small topographic irregularities present in the high 318 resolution of the LiDAR data, in particular the trails that we sampled along (the smoothed grid 319 still had a $3 \mathrm{~m}$ cell size).

320 Point locations of the sampled soil profiles were then assigned terrain attributes (slope and 321 plan and profile curvature) from the smoothed surfaces. Because the relatively small number of 322 sampling sites could make it difficult to detect significant contrasts in topographic setting 323 between the forest-covered Mollisols and other soils, we also applied the same methods to large 
324 numbers of randomly located points in polygons of Mollisols and adjacent Alfisols on colluvial

325 slopes in the Houston County soil survey (Lueth, 1984, available as digital SSURGO data). One

326 set of 31,700 points was sampled within polygons of Lacrescent and Brodale soils, Mollisols on

327 steep upper slopes similar to those we targeted for sampling (Fig. 3). Another 31, 701 points

328 were sampled in polygons of Alfisols (Council, Elbaville, and Seaton valley phase) typically

329 mapped immediately downslope from Lacrescent and Brodale soils, on footslopes mantled by

330 the Sm or Fm lithofacies (Fig. 3).

331 To study vegetation change within the last $160 \mathrm{yr}$, we used a GIS dataset of vegetation at

332 intersections of the grid laid out during the original 1854 public land survey of the study area,

333 interpreted from surveyors' field notes (Almendinger, 1997). Using digital soil survey data, we

334 selected 232 section and quarter section corners (the survey grid intersections) that fell within

335 polygons of Brodale and Lacrescent soils, excluding a few that were in locations where error in

336 mapping is highly likely (e.g. where polygons of those soils were drawn as if they extended onto

337 valley floors). The vegetation types recorded on these Mollisols in 1854 were then tabulated

338 separately for corners on slopes with south $\left(90^{\circ}\right.$ to $270^{\circ}$ azimuths $)$ and north $\left(0^{\circ}\right.$ to $90^{\circ}$ and $270^{\circ}$

339 to $0^{0}$ azimuths) aspects. Virtually all slopes with Lacrescent soils on north aspects are forest-

340 covered today, so we were especially interested in whether the land survey notes record prairie or

341 savanna on those slope aspects in 1854.

\subsection{Statistical analysis at the soil horizons level}

As in most soil genesis research, we initially focused on relationships between whole-profile 
347 relationships for our research question, such as those between OC accumulation and $\mathrm{Ca}^{++}$

348 abundance, texture, or mineralogy should be evident at the level of individual horizons.

349 Analyzing those relationships at the horizon level is especially important because most of the

350 soils we sampled have heterogeneous parent materials, resulting in substantial variation among

351 horizons in texture, mineralogy, and rock fragment content. Thus, we used principal component

352 analysis (PCA) and linear models to examine relationships between parent material-related

353 properties and OC content in individual horizons, and then considered which of those horizon-

354 level relationships can help explain variations in whole-profile morphology across the hillslopes

355 we studied.

356 The content of OC decreases greatly with depth in all the sampled profiles; however, the key

357 issue of interest is the degree to which the OC content of a horizon at a particular depths is

358 anomalously high or low, as compared to other horizons at that depth in the whole set of soils

359 sampled at all sites. To determine that, standard \%OC profile representing the average of all

360 individual soil OC profiles was calculated by 1-cm depth increments, assigning each increment

361 the average \%OC for all individual horizons that include that depth increment. We then

362 calculated the differential OC content of each horizon:

363

Diff $\mathrm{OC}=\mathrm{OC}_{\mathrm{i}, \mathrm{z1}-\mathrm{z} 2}-\mathrm{OC}_{\mathrm{ave}, \mathrm{z} 1-\mathrm{z} 2}$

364 where $\mathrm{OC}_{\mathrm{i}, \mathrm{z1}-\mathrm{z} 2}$ is measured \%OC between depths $\mathrm{z} 1$ and $\mathrm{z} 2$ (upper and lower horizon

365 boundaries) for a particular sample, and $\mathrm{OC}_{\mathrm{av}, \mathrm{z1}-\mathrm{z2} 2}$ is the average \%OC for that depth interval in

366 the standard \%OC profile. In essence, Diff OC of an individual horizon is the deviation of its

367 OC content from the standard profile.

368 Principal components analysis (PCA) was used to explore the major axes of variation in soil 369 horizon properties, in terms of Diff OC as well as potentially parent material-related properties 
370 of individual horizons. This analysis used 111 individual A to C horizon samples from a subset

371 of 18 soil profiles (Table 1) for which clay mineralogy data were available, and the input

372 variables were $\mathrm{pH}$, Diff OC, particle size fractions (sand, silt, clay), and clay mineral fractions

373 (smectite, illite, vermiculite, kaolinite+chlorite). The raw percentages of particle size and clay

374 mineral fractions were transformed using centered log ratios to avoid the inflated correlations

375 associated with compositional data that sum to $100 \%$ (Kucera and Malmgren, 1998). The PCA

376 was implemented using the PRINCOMP module of R (R DevelopmentTeam, 2008); the

377 correlation matrix was used, equivalent to standardizing the original variables, which differ in

378 units and variance. Based on the results of PCA, we used R to test linear models in which

379 potentially parent material-related properties were used as predictors of Diff OC for the same

380111 individual horizons, using the Akaike Information Criterion (AIC) (Akaike, 1973) to

381 evaluate the information gained by adding predictor variables.

383 3. Results

\subsection{Soil morphology in relation to hillslope stratigraphy}

The 29 soils that we studied varied most strikingly in A horizon thickness and color. Using those characteristics, the soils were placed in two groups, one of which was subdivided based on

389 dolomite rock fragment content (Fig. 5). Group 1 includes 17 Mollisols at the four hillslope sites 390 (e.g. RN-4 and CAR-7, Fig. 5), all of which have A and AB horizons with moist Munsell value 391 and chroma of 3/3 or darker totaling $>25 \mathrm{~cm}$ in thickness (the basic requirements for mollic 392 epipedons). Of these, 10 are under forest (at RN, RH, and CAR sites), and seven under prairie 
393 (all soils at SF site and CAR-12) (Fig. 4, Table 1). Most Group 1 soils (12 of 17) have Bw

394 horizons with well-expressed pedogenic structure but little or no field evidence of clay

395 illuviation. Three others, all under forest, have Bt horizons identified in the field by clay coatings

396 on peds or in pores and possible small increases in clay from A to B horizons. One Group 1 soil

397 (SF-4) has no B horizon and the B horizon was not exposed enough to characterize in CAR-12.

398 Most of the Group 1 soils (15 of 17) clearly formed in the Dc lithofacies (Fig. 2) and have

399 visually estimated B horizon rock fragment contents $>20 \%$ (virtually all dolomite), although rock

400 fragment content decreases to $<5 \%$ in upper A horizons of some of these soils. The exceptions

401 are a soil formed in $27 \mathrm{~cm}$ of stone-free silt over dolomite bedrock (SF-4), and one formed

402 mainly in weathered sandstone but with some dolomite fragments (SF-6). Despite the high

403 content of dolomite fragments throughout much of the profile in Group 1 soils, the fine earth is

404 not effervescent with 10\% $\mathrm{HCl}$ above a depth of 50-70 cm in Group 1 profiles from CAR, RH,

405 and RN sites. Strong to violent effervescence of the fine earth was observed below that depth.

406 At the south-facing SF site, all but the upper A horizon generally effervesced with $10 \% \mathrm{HCl}$, and

407 most dolomite fragments in lower A and B horizons have well-developed pedogenic carbonate

408 pendants on their undersides. No redoximorphic features or low-chroma colors indicating past or

409 present soil wetness were observed in any Group 1 soil.

410 Group 2 is composed of nine soils at the hillslope sites (e.g. CAR-1 and RH-5, Fig. 5) and the

411 three thick loess soils. In this group, A or AB horizons with value and chroma of 3/3 or darker

412 have total thickness $<25 \mathrm{~cm}$ (often much $<25 \mathrm{~cm}$ ). All but two of the Group 2 soils are Alfisols

413 with Bt horizons identified in the field by texture and clay coatings and argillic horizons

414 confirmed by laboratory particle size data; most also have distinct E horizons. The exceptions

415 (CAR-2 and RN-2) are Inceptisols with Bw horizons. Group 2 soils can be divided into two 
416 subgroups, based on parent material. Group 2A soils include the three formed in ridgetop loess

417 and four formed in a thin mantle of the sandy Sm lithofacies that extends downhill over the silt-

418 rich Fm lithofacies on lower footslopes (Fig. 2). Upper horizons of the latter four soils have high

419 sand content, but Bt horizons are more silt-rich. Group 2A soil profiles are non-effervescent in

420 all horizons. In contrast, the five soils in Group 2B (CAR-3, RN-2, RN-4, RN-5, and RH-5)

421 contain relatively abundant dolomite fragments in lower horizons, where the fine earth matrix is

422 also effervescent. The parent material of three of these soils is clearly the Dc lithofacies. The Bt

423 horizon clay content and color in the other two (RN-4 and -5) suggest they formed in a mixture

424 of the Dc lithofacies the reddish brown clays that underlie loess on ridgetops, possibly resulting

425 from cryoturbation. One Group 2B soil, RH-5, forms an especially interesting contrast with the

426 Group 1 soil RH-4, only $5 \mathrm{~m}$ away along the same roadcut face (Fig. 5).

427

428

\subsection{Topographic setting}

429

colluvial hillslopes (including our Group 1 soils) closely corresponds to steep upper slopes with

432 convex or planar profiles, while the soils with thinner A horizons just downhill are on gentler

433 concave slopes. Our quantitative analysis supports that view as a broad generalization, but

434 indicates substantial variation in local topographic settings of these soils (Fig. 6). The 31,701-

435 point sample from soil survey polygons of Mollisols similar to our Group 1 soils displays a wide

436 range of curvatures, with a slightly negative median value of -0.03 , indicating a slightly convex

437 slope profile (Fig. 6a) This sample includes slopes ranging from $2^{0}$ to $42^{0}$ (median of $26^{0}$ ),

438 possibly exaggerating the actual range for these soils because it is clear that some of the 
originally hand-drawn soil survey polygons were erroneously extended onto ridgetops or footslopes. The soil survey-based sample of Alfisols typically mapped just downslope of those Mollisols displays a distinctly more concave (positive) median profile curvature of 0.22 (Fig. $6 a$ ), with slopes ranging from $<1^{0}$ to $26^{0}$ (median of $9^{0}$ ). The profile curvature distributions for these two large samples are significantly different $(p<0.001)$, based on a two-sample

Kolmogorov-Smirnov test (k.test in R). The distributions of profile curvature for the 17 Group 1 soils (Fig. 6b) and the large sample of similar Mollisols are not significantly different $(p=0.19)$, but the Group 1 distribution is significantly different from the one for the large sample of Alfisols on lower slopes ( $p=0.001$ ). The median profile curvature for Group $1,-0.37$, is more convex than for the large Mollisol sample, however, and the Group 1 soils are on relatively steep slopes (range of $18^{0}$ to $33^{0}$, median of $31^{0}$ ).

The nine Group 2 soils that we sampled on hillslopes have range of convex to concave profile curvatures (Fig. 6b), with a slightly convex median of -0.09 , and their distribution is not significantly different from those of Group 1, the large Mollisol sample, or the large Alfisol sample (not surprising given the small sample size). Our Group 2 soils are on relatively steep slopes, compared to the large Alfisol sample, however (range of $17^{0}$ to $31^{0}$, median of $26^{0}$ ).

Median plan curvature is positive, indicating topographic settings where surface water flow lines would diverge, for Group 1 (0.10), Group 2 (0.16), and both large samples (0.11 for Mollisols, 0.02 for Alfisols); none of the distributions of plan curvature are significantly different from any others $(p>0.05$ in all cases).

The most important result of this topographic analysis is that despite considerable local variability, our Group 1 soils and similar Mollisols on colluvial slopes in the study area are not typically on concave slopes of relatively low gradient, in areas of convergent flow (concave plan 
462 curvature). That is, they are not in parts of the landscapes found to have relatively high

463 accumulation of soil OC in modeling and observational studies where topographic effects were

464 significant (Aandahl, 1948; Berhe et al., 2008, 2012; Gessler et al., 2000; Schimel et al., 1985;

465 Yoo et al., 2006). Only the large sample of Alfisols on footslopes tends to be in those

466 topographic settings, yet those soils display much thinner A horizons and probably contain much

467 less OC than the Mollisols higher on the slopes. Our sample of Group 2 soils, though mainly

468 Alfisols, is from steeper and less concave slopes than the larger Alfisol sample, and in some

469 cases intermixed with Group 1 soils in very similar topographic settings (e.g. RN and RH sites,

470 Fig. 4).

471

472 3.3. OC content, texture, mineralogy, and $\mathrm{pH}$

473

474

As expected from contrasts in A horizon thickness and color, soils in Group 1 tend to have

475 higher OC content at a given depth than those in Group 2 above a depth of $70 \mathrm{~cm}$, as shown by

476 plots of average OC by depth for each group and across all the soils (Fig. 7). Individual samples

477 display considerable scatter and overlap between the groups, however. Group 2A and Group 2B

478 have very similar profiles when averaged separately (not shown). The Diff OC variable is

479 essentially the distance to the right or left of the overall average profile shown in Figure 7, so

480 soils in Group 1 generally have higher Diff OC values than those in Group 2.

481 The texture, $\mathrm{pH}$, and clay mineralogy of the soils are all strongly related to parent materials,

482 though overprinted to varying degrees by pedogenesis, particularly for the Group 2 soils (Fig. 8).

483 The three Group 1 soils and the Group 2B soil (RH-5) shown in Figure 8 all have fine earth

484 textures within the broad range observed in the matrix of the Dc lithofacies that they formed in. 
485 This matrix is a mixture of sand derived mainly from local bedrock and silt and clay from Peoria 486 Loess (Mason, 1992), with the proportions often varying considerably across hillslopes and with 487 depth in individual profiles. Comparison with the lower horizons of the AL profile, formed 488 entirely in Peoria Loess, indicates that the clay mineralogy of Group 1 and Group 2B soils is 489 largely inherited from the loess added to the Dc matrix, though minor amounts of clay may come 490 from weathered bedrock. In Group 2A soils formed in the Sm and Fm lithofacies (e.g. CAR-1, 491 Fig. 5, 8) much of the clay is probably loess-derived, but in some cases relatively high kaolinite 492 content may reflect some clay input from the sandstone bedrock. The upper part of the AL and 493 CAR-1 profiles (Group 2A) displays distinct depletion of smectite, probably through a 494 combination of eluviation and conversion to hydroxy-interlayered forms which are counted as 495 vermiculite; otherwise, there is little evidence of pedogenic alteration of the clay mineralogy 496 inherited from parent materials.

497 Presence or absence of carbonate minerals is clearly the predominant influence on $\mathrm{pH}$ in 498 these soils (Fig. 8). As noted above, Group 1 soils typically contain coarse fragments of dolomite 499 throughout the profile, and they are present in lower horizons of Group 2B soils. Across all 500 sampled soils, horizons that effervesce in $10 \% \mathrm{HCl}$ and contain dolomite fragments have $\mathrm{pH}$ 501 values between 7.0 and 8.2, consistent with $\mathrm{pH}$ controlled by equilibrium with carbonates. Non502 effervescent horizons containing coarse dolomite fragments have $\mathrm{pH}$ values of 6.5 to 7.5. 503 Horizons from Group 2 soils that lack dolomite fragments and are non-effervescent all have $\mathrm{pH}$ 504 <.0, and in many cases have pH between 4.8 and 6.0 (e.g. CAR-1 and AL profiles in Fig. 8). 505 Statistical analyses highlight the range of variation of texture and mineralogy within groups, 506 that is, the contrast in A horizon morphology between Groups 1 and 2 is only one dimension of 507 the variability of these soils. Nonetheless, these analyses clearly identify $\mathrm{pH}$ as a variable 
associated with high Diff OC, and therefore also point to parent material dolomite content as a key explanation for the morphological contrasts between Groups 1 and 2. The 111 samples used in these analyses come from nine Group 1 soil profiles (53 horizons), five Group 2A profiles (33 horizons), and four Group 2B profiles (35 horizons) (Table 1), using A to BC or $\mathrm{C}$ horizons from each profile.

The results of PCA can be interpreted using biplots of individual horizon sample scores on the first three principal components (PC1, PC2, and PC3), which together account for $86.5 \%$ of the variance in the input data (Fig. 9, Table 2). Of these, PC1 and PC2 (65.8\% of the variance) are most heavily loaded by particle size and clay mineral fractions, with smaller but substantial loading by Diff OC as well (Fig. 9a). A biplot of horizon sample scores on PC1 and PC2 (Fig. 9b) reveals the large textural and mineralogical variation within morphological groups, more than distinctions between them. Group 1 samples mostly cluster near the center of the plot, reflecting intermediate textures and a mixture of clay minerals. Several Group 1 samples plot farther to the right (PC1 > 2), however. These are mostly samples from deeper BC and C horizons with relatively low Diff OC and higher sand and kaolinite content than other Group 1 samples, reflecting greater contribution of sandstone bedrock. Group 2A horizons occur in three distinct locations on the PC1-PC2 biplot (Fig. 9b). Several, from a loess-derived ridgetop soil, plot far to the upper left (PC1-, PC2+), to a large extent because of high silt and clay content, and some cases also a relatively high proportion of illite. Another cluster of Group 2A horizons falls in the lower right quadrant (PC1+, PC2-); these formed in the sandy Sm lithofacies and have relatively high sand, kaolinite, and vermiculite contents. Still other Group 2A samples overlap those from Group 1 near the center of the plot. Group 2B horizons are widely distributed on the PC1-PC2 plot, overlapping areas occupied by samples from both Group 1 and Group 2A. 
The morphological groups are much more clearly separated on a biplot of PC2 and PC3 (Fig.

532 9d), though mainly along PC3. While PC3 accounts for only $20.7 \%$ of total variance, it is the

533 first component strongly loaded by $\mathrm{pH}$ and it is also loaded in the same negative direction by

534 Diff OC (Fig. 9c). Almost all Group 1 horizons fall in the lower half of the PC2-PC3 biplot (Fig.

535 9d), with most in the lower right quadrant (PC2+, PC3-), mainly reflecting their high pH and

536 Diff OC; deeper Group 1 horizons (BC and C) with higher illite tend to be toward the right (high

537 PC2) side of the Group 1 cluster. Group 2A horizons are almost all in the upper half of the PC2-

538 PC3 biplot, largely because of lower $\mathrm{pH}$ and/or Diff OC, along with high vermiculite or kaolinite

539 proportions in some samples. Acidic Group 2A A and E horizons plot especially high on PC3.

540 Group 2B horizon samples plot in areas occupied by both Group 1 and Group 2A samples.

541 Dolomite-rich B and C horizons from Group 2B plot close to many Group 1 horizons.

542 To summarize, PCA reveals a great deal of interesting textural and mineralogical variation

543 within morphological groups, much of which may ultimately be related to heterogeneous parent

544 materials. Despite their striking morphological contrast, Groups 1 and 2A clearly separate only

545 along one of the major axes of variation identified by PCA. That axis, PC3, is most strongly

546 loaded by $\mathrm{pH}$ and Diff OC, clearly suggesting that $\mathrm{pH}$ (or dolomite content) was an important

547 factor in the OC accumulation that formed the thick A horizons of Group 1. Diff OC is loaded

548 almost as strongly on PC1, however, in the same direction as clay, silt, and smectite, suggesting

549 an association between texture and OC accumulation for individual horizons, if not for

550 morphological groups.

551 With that background, we tested linear models for prediction of Diff OC in the same set of

552111 horizon samples, from either $\mathrm{pH}$ or a textural variable alone, and from combinations of $\mathrm{pH}$

553 and a textural variable (Table 3). Either \% sand or \% clay alone is a significant, though quite 
554 weak, predictor of Diff OC; pH alone explains almost none of the variance in Diff OC.

555 Combining \% sand, or especially \% clay, with $\mathrm{pH}$ yields substantially better predictive equation

556 (adjusted $\mathrm{R}^{2}=0.56$ for $\%$ clay and $\mathrm{pH}$ ), although it still only explains about half of the variance

557 in Diff OC. Adding a clay mineral variable (proportion of smectite, vermiculite, illite, or

558 kaolinite+chlorite) does not improve the model, based on AIC (two examples shown in Table 3).

559 The residuals from the model using \% clay and $\mathrm{pH}$ as predictors indicate substantial

560 underestimation of six highest Diff OC values, and overestimation of the four lowest, but the

561 other 101 residuals are normally distributed.

562 These results can be explained by considering the varying relations between texture, $\mathrm{pH}$, and

563 Diff OC with depth in the horizon samples used for this analysis, Diff OC (not just total OC) is

564 greatest in the upper horizons of Group 1 soils, which also tend to contain more clay and less

565 sand than deeper horizons; $\mathrm{pH}$ is relatively high throughout many of these soils. Thus, within

566 Group 1, sand or especially clay content may be a better predictor of Diff OC than $\mathrm{pH}$. On the

567 other hand, pH differentiates Group 1 from Group 2A or 2B, for upper horizons with similar clay

568 or sand content but contrasting Diff OC. Clay mineralogy does not appear to be significantly

569 related to anomalously high or low OC accumulation in the soils we sampled.

570

571 3.4. Stable isotope analysis and radiocarbon dating

572

573 Results discussed here are based on OC and N isotopic data from 13 vertical profiles in

574 Group 1 soils (Table 1). One of these was profile CAR-12 which was sampled only for isotopic

575 analysis, and four were profiles that were essentially replicates of CAR-7, distributed at $5 \mathrm{~m}$

576 intervals over $20 \mathrm{~m}$ away from that profile along the same vertical face, and sampled only for 
577 isotopic analysis. Five Group 2 soils were also sampled for isotopic analysis, three from Group

$578 \quad 2 \mathrm{~A}$ and two from 2B (Table 1).

$579 \quad$ All C isotopic results are reported as $\delta^{13} \mathrm{C}$ VPDB, the ratio of ${ }^{13} \mathrm{C}$ to ${ }^{12} \mathrm{C}$ normalized by the 580 ratio in the standard Vienna Pee Dee Belemnite, in per mil (\%o) units; N isotopic data are 581 reported as $\delta^{15} \mathrm{~N}$, the ratio of ${ }^{15} \mathrm{~N}$ to ${ }^{14} \mathrm{~N}$ normalized by the isotopic ratio of atmospheric $\mathrm{N}$.

582 Radiocarbon dating of OC from CAR-7 indicates that the mean residence time of OC increases 583 substantially with depth, given a modern age at $5 \mathrm{~cm}$ and $895 \pm 30{ }^{14} \mathrm{C}$ yr BP at $45 \mathrm{~cm}$ (Table 4). 584 This trend of increasing age with depth is widely observed and expected for most soils because 585 of low rates of OC addition and decomposition in deeper horizons (Scharpenseel, 1971; Wang et 586 al., 1996). Assuming OC mean residence time increases with depth in this fashion in all of the 587 soils we studied, deeper samples are dominated by OC added earlier in time, and depth trends of $588 \quad \delta^{13} \mathrm{C}$ can potentially be interpreted as the result of vegetation change.

589 The most straightforward results were from the three Group 2A soils, all currently under 590 forest (Fig. 10a). Near the ground surface in these soils, $\delta^{13} \mathrm{C}$ is $-28 \%$ o to $-26 \%$, close to the 591 mean value of $-28 \%$ for OC from $C_{3}$ plants when freshly added to the soil (Boutton, 1996). All 592 three Group 2A profiles display trends of increasing (less negative) $\delta^{13} \mathrm{C}$ with depth, with a total 593 increase of 2-4\%. A downward increase of this magnitude is common and is generally attributed 594 to a combination of more advanced organic matter decomposition in deeper horizons, greater 595 input of less ${ }^{13} \mathrm{C}$-depleted root biomass relative to leaf litter with increasing depth, and the 596 influence of fossil fuel combustion on isotopic composition of atmospheric $\mathrm{CO}_{2}$ (the Suess 597 effect). The isotopic shift during decomposition is likely the largest factor, although the specific 598 mechanisms involved are still a matter of discussion (Bostrom et al., 2007; Ehleringer et al., 599 2000; Nadelhoffer and Fry, 1988; Wedin et al., 1995; Wynn et al., 2005; Wynn et al., 2006). No 
600 past input from $\mathrm{C}_{4}$ plants is necessary to explain this modest shift in $\delta^{13} \mathrm{C}$ with depth. The value 601 of $\delta^{15} \mathrm{~N}$ increases with depth and C:N decreases with depth in Group 2A profiles (Fig. 10b-c).

602 Both trends are commonly reported; the C:N decrease is attributed to decomposition, while the 603 increase in $\delta^{15} \mathrm{~N}$ results from decomposition effects, fractionation during transfer of $\mathrm{N}$ from 604 mycorrhizal fungi to host plants, and $\mathrm{N}$ loss through nitrification and denitrification (Hobbie and 605 Ouimette, 2009; Melillo et al., 1989; Nadelhoffer and Fry, 1988). In these profiles $\delta^{13} \mathrm{C}$ and $\delta^{15} \mathrm{~N}$ 606 are positively correlated $\left(\mathrm{R}^{2}=0.80\right)$, as expected if both are strongly influenced by greater 607 decomposition with depth. The slope of this relationship is 1.81 (Fig. 11a).

608 Interpretation of isotopic profiles from the four Group 1 soils that are under prairie grass609 dominated vegetation today (three from the SF site plus CAR-12) is also fairly straightforward 610 (Fig. 10a-c). These soils have OC with $\delta^{13} \mathrm{C}$ values between -16\% and -13\%o, indicating organic 611 matter inputs largely dominated by $\mathrm{C}_{4}$ plants (mean value of $-13 \%$; Boutton, 1996). These soils 612 do not consistently display depth trends of $\delta^{13} \mathrm{C}$ or $\mathrm{C}: \mathrm{N}$ that would indicate decomposition 613 effects; however, $\delta^{15} \mathrm{~N}$ does increase consistently with depth in three of the four profiles and $\delta^{13} \mathrm{C}$ 614 and $\delta^{15} \mathrm{~N}$ are weakly positively correlated $\left(\mathrm{R}^{2}=0.42\right)$, with a slope of 1.12 (Fig. 11a). A stronger 615 depth trend might have been apparent if we had sampled these soils closer to the ground surface 616 (the uppermost samples we analyzed were composited from the thick uppermost A horizons).

617 The weakness of depth trends may also reflect the large belowground input of fresh carbon from 618 roots in the prairie ecosystem. Importantly, the $\delta^{15} \mathrm{~N}$ and $\mathrm{C}: \mathrm{N}$ values for horizons of these soils 619 under prairie overlap with those from similar depths in forest-covered Group 2A (Fig. 10b-c).

620 Isotopic profiles of OC are distinctly different in the profiles of Group 1 soils that are under

621 forest today and from Group 2B soils, also under forest (Fig. 10d-f). All of these soils display 622 similar steep trends of increasing $\delta^{13} \mathrm{C}$ with depth (Fig. 10d), with a shift of 4 to $7 \%$ between 
623 samples at 5-10 cm depth and those from $>30 \mathrm{~cm}$. Near-surface $\delta^{13} \mathrm{C}$ is in the range expected

624 for largely $\mathrm{C}_{3}$-derived OC, consistent with the modern forest cover on these soils. Values of $\delta^{13} \mathrm{C}$

625 at depth are as high as -19 to $-17.5 \%$, which are difficult to explain without substantial input

626 from $\mathrm{C}_{4}$ vegetation at some time in the past. The shift with depth is much larger than that

627 attributed to effects of decomposition in prior research (Bostrom et al., 2007; Ehleringer et al.,

628 2000; Nadelhoffer and Fry, 1988; Wedin et al., 1995; Wynn et al., 2005). Furthermore, if we

629 were to try to explain this large shift through decomposition alone, we would expect to find

630 values of $\delta^{15} \mathrm{~N}$ and $\mathrm{C}: \mathrm{N}$ at depth also recording an extraordinary degree of decomposition.

631 Instead, the $\delta^{15} \mathrm{~N}$ and $\mathrm{C}: \mathrm{N}$ profiles in these 11 soils are generally similar to those of all the others

632 that were analyzed (compare Fig. 10e-f with Fig. 10b-c), suggesting that large differences in the

633 degree of decomposition in deeper horizons cannot explain contrasts in C isotope profiles.

634 Combining Group 1 soils under forest and Group 2B soils, $\delta^{13} \mathrm{C}$ and $\delta^{15} \mathrm{~N}$ are positively

635 correlated $\left(\mathrm{R}^{2}=0.81\right)$, but with a much lower slope (0.66) than for the other soils (Fig. 11a). That

636 is, $\delta^{15} \mathrm{~N}$ displays a smaller increase with depth in these soils, for a given increase in $\delta^{13} \mathrm{C}$. This is

637 expected if $\delta^{15} \mathrm{~N}$ increases largely through effects of decomposition, while the increase in $\delta^{13} \mathrm{C}$

638 reflects the shift due to decomposition superimposed on a larger shift caused by vegetation

639 change.

640 In summary, Group 2A soils under forest and Group 1 soils under prairie yielded C isotope

641 profiles that can be explained as the result of decomposition, combined with the Suess effect and

642 greater input from roots at depth, but without vegetation change. In contrast, the Group 1 soils

643 and Group 2B soils all have considerably larger increases of $\delta^{13} \mathrm{C}$ with depth, which appear to

644 require vegetation change for adequate explanation, especially when profiles of $\delta^{13} \mathrm{C}$ are

645 compared to those of $\delta^{15} \mathrm{~N}$ and $\mathrm{C}: \mathrm{N}$. The implied vegetation change is from a mixture of $\mathrm{C}_{4}$ 
grasses and $\mathrm{C}_{3}$ plants, to vegetation with near-complete $\mathrm{C}_{3}$ dominance, most likely forest. All of

647

648

649

650

651

652

653

654

655

656

657

658

659

660

661

662

663

664

665

666

667

668 these soils that preserve evidence of vegetation change contain coarse dolomite samples

throughout the profile or in deeper horizons, although it should be emphasized that the dolomite does not contribute to the isotope shift because the samples were treated to remove carbonates.

The four replicate profiles sampled at 5-m intervals adjacent to CAR-7 (a Group 1 soil under forest) provide one additional insight, although we only collected two samples from each of these profiles (Fig. 11b). All four display a shift toward less negative $\delta^{13} \mathrm{C}$, as does CAR-7, but

there is considerable local variability in $\delta^{13} \mathrm{C}$ at a given depth and in the slope of the depth trend. Thus, although the four replicate profiles are very similar in morphology to the CAR-7 profile studied in detail, they could differ significantly in the degree of decomposition at a given depth, or even in past vegetation history.

\subsection{Vegetation change since the public land survey}

Public land survey records from 1854 indicate considerable areas of vegetation more open than closed forest on steep colluvial slopes, on both north and south aspects but especially on the latter (Table 5). Specific vegetation structure cannot be accurately inferred from many of the terms used by land surveyors for open vegetation (e.g. “dry ridge” and “scattering oaks”), but probably ranged from small areas of treeless prairie to more extensive savanna and open woodland. This interpretation is supported by the typical absence of witness trees (nearby trees recorded at corners to allow the survey markers to be relocated) where vegetation was described as prairie or “dry ridge”, and the predominance of bur oak (Quercus macrocarpa) when witness trees are recorded in vegetation described as "scattering oaks”, "oak barrens," etc. In the 
669 nineteenth century, fire-tolerant bur oak was commonly observed in open stands with grass

670 understories (Curtis, 1959).

671 What is particularly notable about the land survey records is that relatively open vegetation is

672 recorded on 52\% of north-facing colluvial slopes, virtually all covered by closed forest today.

673 While no corners are close enough to our study sites to infer vegetation change there, these

674 results do suggest that soils on forest-covered north-facing slopes at the CAR, RN, and RH sites

675 could have had more open vegetation with abundant grasses as recently as 160 years ago. While

676 there are large trees that may be older than $160 \mathrm{yr}$ at all three sites, they are scattered enough that

677 they could have once formed part of a savanna or open woodland.

678

679 4. Discussion

680

We found no evidence that topographic setting can explain the occurrence of thick, dark A 682 horizons under forest in our study area. Quantitative analysis indicates that the soils of Group 1 683 are not generally in topographic settings found to favor OC accumulation in previous research 684 (Aandahl, 1948; Berhe et al., 2008, 2012; Gessler et al., 2000; Schimel et al., 1985; Yoo et al., 685 2006). In fact, lower concave slopes that might favor OC accumulation in other landscapes are 686 actually occupied by Alfisols and other soils with thin A horizons in the study area. Some of our 687 Group 2 soils are in topographic settings very similar to Group 1 soils, also suggesting that 688 topographic effects are not important in explaining the morphological contrast between groups.

689 Low erosion rates under closed forest or dense grassland may help explain why topographic 690 effects on soil OC are not more evident on the slopes we studied, as opposed to landscapes 691 affected by long-term anthropogenic erosion (Doetterl et al., 2012). 
The relative importance of parent material and vegetation history is a more complex issue.

693 Without the stable C isotopic data and the land survey records, the rest of our results could lead

694 us to interpret thick, dark OC-rich A horizons as primarily the result of parent materials rich in

695 dolomite fragments. Such horizons occur under forest as well as prairie, but only in the

696 dolomite-rich Dc lithofacies, consistent with parent material control. Specifically, without

697 additional information, we could interpret thick OC-rich A horizons mainly as an effect of

698 abundant $\mathrm{Ca}^{++}$and $\mathrm{Mg}^{++}$released by weathering dolomite, which may favor development of

699 organic matter-mineral cation bridges and more generally favors especially stable aggregation,

700 both of which act to stabilize OC (Oades, 1988, von Lützow et al., 2006). That in turn could lead

701 to slower OC turnover and accumulation of a larger pool in the A horizon, regardless of

702 vegetation structure. Higher clay and silt content also appear to be associated with greater OC

703 accumulation in individual horizons at a given depth in these soils, possibly also by allowing

704 more stable aggregation. Nonetheless, the presence or absence of dolomite fragments is the

705 parent material effect most clearly distinguishing the groups of soils we defined by A horizon

706 morphology.

707 The stable C isotopic data, however, provide clear evidence that Group 1 soils with thick,

708 dark, OC-rich A horizons that are under forest cover today contain substantial $\mathrm{C}_{4}$-derived OC

709 preserved in deeper horizons. That is, they must have formed partly under grassland or savanna

710 with relatively abundant $\mathrm{C}_{4}$ grasses. Interestingly, the two Group 2B soils we sampled for

711 isotopic analysis, Alfisols with thinner A horizons formed in dolomite-rich parent material, also

712 preserve isotopic evidence of past $\mathrm{OC}$ input from $\mathrm{C}_{4}$ grasses. The land survey data also

713 demonstrate that many forest-covered slopes where thick, dark A horizons occur had more open

714 vegetation, most likely including a grass understory, as recently as the mid- $19^{\text {th }}$ century. 
715 Replacement of open vegetation by forest could be the result of wildfire suppression after

716 Euroamerican settlement of the study area, beginning in the mid-19 ${ }^{\text {th }}$ century; this is a common

717 explanation for similar vegetation change in other parts of the Midwest (Curtis, 1959). On the

718 other hand, there is good evidence for a somewhat longer-term Late Holocene trend of

719 climatically driven forest expansion in nearby areas, as discussed above (Grimm, 1983; Shuman

720 et al., 2009; Umbanhowar, 2004).

721

Taking all lines of evidence into account, the thick, dark-colored A horizons of Group 1 soils

722 occur almost entirely in the dolomite-rich Dc lithofacies, under prairie at present or under forest

723 that has probably replaced prairie or savanna with abundant $\mathrm{C}_{4}$ grasses. Two hypotheses can

724 explain this pattern. First, prairie or savanna could have occurred on north as well as south slope

725 aspects in the past, but was limited to the steep upper slopes mantled by the Dc lithofacies. This

726 would account for restriction of Group 1 soils to that setting today. Alternatively, prairie or

727 savanna may have covered much more of the landscape in the past, but older $\mathrm{C}$ with the isotopic

728 signature of $\mathrm{C}_{4}$ plants is better preserved today in Group 1 soils formed in the Dc lithofacies than

729 in other soils on the same hillslopes.

730 The first hypothesis cannot be ruled out without direct evidence for the past presence of

731 prairie above or below the slope segments now occupied by Group 1 soils at our study sites.

732 There is good reason to doubt this explanation, however. At the local scale where macroclimatic

733 gradients are minimal, boundaries between forest and prairie in the humid Midwestern U.S.

734 generally appear to have been related to spatial variation in fire frequency, which was influenced

735 by topographic or hydrological features that limited the spread of fire and allowed establishment

736 of trees (Grimm, 1984). At our study sites, however, there is no apparent reason why fires would

737 consistently burn only a particular segment of the slope. Especially low soil moisture on certain 
slope segments might conceivably have favored prairie grasses over trees, either directly or through its effect on fire frequency. Given soil textures, however, it is likely the lowest moisture values are actually reached on sandy upper footslopes (Sm lithofacies), not on the steep slopes above mantled by the Dc lithofacies with its siltier matrix (Fig. 2).

The second hypothesis is more likely to be valid. Preferential preservation of isotopic evidence for past $\mathrm{C}_{4}$ vegetation in the Group 1 soils, can in fact be explained by the same effect of abundant dolomite-derived $\mathrm{Ca}^{++}$and $\mathrm{Mg}^{++}$on OC stability that was outlined above. In this case, however, the development of thick OC-rich A horizons in Group 1 soils is not attributed entirely to that effect of parent material lithology. Instead, we suggest that prairie or savanna was present across much of the hillslope at each of the three presently forest-covered study sites, and relatively thick A horizons may have developed in the full range of parent materials under the influence of that vegetation. As closed forest occupied these sites, slower cycling of OC in horizons formed from the dolomite-rich Dc lithofacies led to more prolonged preservation of both thick, dark A horizons and the isotopic signature of prairie grasses.

The second hypothesis suggests that there could be soils that are intermediate in A horizon morphology and preservation of $\mathrm{C}_{4}$-derived $\mathrm{OC}$, because they contain only a few dolomite fragments or they have sandy textures that limit OC accumulation. Soils of Group 2B, are in some cases intermediate in A horizon morphology, with A horizons less than $25 \mathrm{~cm}$ thick but still thicker than those in Group 2A. The two contrasting profiles only $5 \mathrm{~m}$ apart at the RH site (RH-4, RH-5) offer intriguing evidence in this regard (Fig. 5). Group 1 soil RH-4, with a thick, dark A horizon and a distinctly OC-rich profile, has abundant dolomite fragments throughout the profile and relatively high silt content. Group 2B soil RH-5, with a dark but thin A and a distinct EB horizon has relatively high sand content and few dolomite fragments in its upper horizons, 
761 possibly because they have weathered rapidly in the sandy matrix. These two soils have similar

$762 \quad \delta^{13} \mathrm{C}$ values in deeper horizons indicating past importance of $\mathrm{C}_{4}$ grasses (Fig. 10d). Thus, even if

763 RH-5 has lost more OC from upper horizons than RH-4, after the transition to closed forest,

764 faster turnover in RH-5 has apparently not had as much effect on OC in dolomite-rich deeper

765 horizons.

766

767 5. Conclusion

768

769 On hillslopes of the study area, soils with thick, dark A horizons under closed forest today

770 preserve isotopic evidence that they formed under prairie or savanna in the past. Yet these soils

771 are almost exclusively formed in colluvial parent material that contains coarse dolomite

772 fragments, which is likely to have created soil chemical conditions favorable for OC

773 accumulation and preservation. Other soils nearby are likely to have also sustained prairie or

774 savanna in the past, but preserve no evidence of it today.

775 We propose that parent material controls the response of soils to vegetation change in this

776 landscape. Where it is dolomite-rich, morphological response is slower and/or more limited, and

777 long-term preservation of OC derived from past vegetation in deep horizons is more likely. The

778 key evidence needed to more conclusively test this interpretation, and more generally the effect

779 of abundant dolomite fragments on OC turnover, would be extensive radiocarbon dating of

780 organic matter in soils formed in parent materials ranging from dolomite-rich to dolomite-free.

781 Even without such definitive evidence, the results of this study strongly suggest a need to

782 consider interactions of vegetation history and parent material in interpreting soils near dynamic

783 vegetation boundaries. More broadly, not only parent material but also topographic setting and 
784 soil hydrology could influence the timescale of soil response to vegetation change in other

785 landscapes, resulting in a soil landscape pattern that has only partially adjusted to the most recent 786 changes in vegetation.

787

788

Acknowledgements

789

790

Research funded by the National Science Foundation, Geography and Spatial Sciences

791

Program grants BCS-0751750 (Mason), BCS-0751772 (Jacobs), and BCS-0751911 (Hanson).

792

We thank two anonymous reviewers for helpful comments on this paper, Minnesota DNR staff

793

and private landowners for access to study sites, and Fei Ma, Samantha Greene, Sarah Oplawski

794 Boldt, and Henry Loope for their contributions to lab and field work.

795

796

REFERENCES

797 Aandahl, A.R., 1948. The characterization of slope positions and their influence on the total 798 nitrogen content of a few virgin soils of western Iowa. Soil Sci. Soc. Am. Proc. 13, 449-454.

799

Akaike, H., 1973. Information theory and an extension of the maximum likelihood principle. In:

800

801

802 Petrov, B.N.; Csáki, F. (Eds.), 2nd International Symposium on Information Theory, Tsahkadsor, Armenia, USSR, September 2-8, 1971, Akadémiai Kiadó, Budapest, pp. 267281.

803 Almendinger, J., 1990. The decline of soil organic matter, total-N, and available water capacity 804 following the Late-Holocene establishment of jack pine on sandy Mollisols, north-central 805 Minnesota. Soil Sci. 150, 68-694. 
Almendinger, J., 1997. Minnesota’s bearing tree database. Biological Report 56, Minnesota Department of Natural Resouces, St. Paul, Minnesota.

Anderson, J., Bailey, O., Rai, D., 1975a. Effects of parent materials on the genesis of Borolls and Boralfs in south-central New Mexico mountains. Soil Sci. Soc. Am. Proc. 39, 901-904.

Anderson, J., Silberman, D., Rai, D., 1975b. Humus accumulation in a forested Haploboroll in south-central New Mexico. Soil Sci. Soc. Am. Proc. 39, 905-908.

Bailey, L., Odell, R., Boggess, W., 1964. Properties of selected soils developed near the forestprairie border in east-central Illinois. Soil Sci. Soc. Am. Proc. 28, 257-263.

Baker, R.G., Bettis, E.A., III, Denniston, R.F., Gonzalez, L.A., Strickland, L.E., Krieg, J.R., 2002. Holocene paleoenvironments in southeastern Minnesota; chasing the prairie-forest ecotone. Palaeogeography, Palaeoclimatology, Palaeoecology 177, 103-122.

Baker, R.G., Maher, L.J., Chumbley, C.A., Vanzant, K.L., 1992. Patterns of Holocene Environmental-Change in the Midwestern United-States. Quaternary Research 37, 379-389.

Berhe, A.A., Harden, J.W., Torn, M.S., Harte, J., 2008. Linking soil organic matter dynamics and erosion induced terrestrial carbon sequestration at different landform positions. J. Geophys. Res., 113, G04039.

Berhe, A.A., Harden, J.W., Torn, M.S., Kleber, M., Burton, S.D., Harte, J., 2012. Persistence of soil organic matter in eroding versus depositional landform positions. J. Geophys. Res., 117, G02019.

Bostrom, B., Comstedt, D., Ekblad, A., 2007. Isotope fractionation and 13C enrichment in soil profiles during the decomposition of organic matter. Oecologia 153, 89-98. 
827 Boutton, T.W., 1996. Stable carbon isotope ratios of soil organic matter and their use as

828

829

830

831

832

833

834

835

836

837

838

839

840

841

842

843

844

845

846

847

848

849 indicators of vegetation and climate change, In: Boutton, T.W., Yamasaki, S. (Eds.), Mass

Spectrometry of Soils. Marcel Dekker, New York, pp. 47-82.

Brodie, C.R., Leng, M.J., Casford, J.S.L., Kendrick, C.P., Lloyd, J.M., Yongqiang, Z., Bird, M.I., 2011. Evidence for bias in $\mathrm{C}$ and $\mathrm{N}$ concentrations and $\delta^{13} \mathrm{C}$ composition of terrestrial and aquatic organic materials due to pre-analysis acid preparation methods. Chemical Geology 282, 67-83.

Bronger, A., 1991. Argillic horizons in modern loess soils in an ustic soil moisture regime:

Comparative studies in forest-steppe and steppe areas from Eastern Europe and the United States. Advances in Soil Science 15, 41-90.

Buell, M., Cantlon, J., 1951. A study of two forest stands in Minnesota with an interpretation of the prairie-forest margin. Ecology 32, 294-316.

Cerling, T., Quade, J., Wang, Y., Bowman, J., 1989. Carbon isotopes in soils and paleosols as ecology and paleoecology indicators. Nature 341, 138-139.

Chumbley, C.A., Baker, R.G., Bettis, E.A., III, 1990. Midwestern Holocene paleoenvironments revealed by floodplain deposits in northeastern Iowa. Science 249, 272-274.

Curtis, J.T., 1959. The vegetation of Wisconsin. University of Wisconsin Press, Madison, Wisconsin.

Doetterl, S., Six, J., van Wesemael, B., van Oost, K., 2012. Carbon cycling in eroding landscapes: geomorphic controls on soil organic C pool composition and C stabilization. Global Change Biology 18, 228-2232.

Dokuchaev, V.V., 1883. Russian Chernozem. [English translation, Israel Program for Scientific Translation, Jerusalem, 1967], Moscow. 
850 Ehleringer, J.R., Buchmann, N., Flanagan, L.B., 2000. Carbon isotope ratios in belowground

851

852

853

854

855

856

857

858

859

860

861

862

863

864

865

866

867

868

869

870

871 carbon cycle processes. Ecol. Applic. 10, 412-422.

Finley, R.W., 1976. Original vegetation cover of Wisconsin, compiled from U.S. General Land Office notes (1:500,000 map). University of Wisconsin Extension, Madison.

Frolking, T., Jackson, M.L., Knox, J.C., 1983. Origin of red clay over dolomite in the loesscovered Wisconsin Driftless Upland. Soil Sci. Soc. Am. J. 47, 817-820.

Gee, G.W., Bauder, J.W., 1986. Particle size analysis, In: Klute, A. (Ed.), Methods of Soil Analysis, Part 1, 2nd ed. American Society of Agronomy, Madison, WI, pp. 383-411.

Geis, J., Boggess, W., Alexander, J., 1970. Early effects of forest vegetation and topographic position on dark-colored, prairie-derived soils. Soil Sci. Soc. Am. Proc. 34, 105-111.

Gessler, P.E., Chadwick, O.A., Chamran, F., Althouse, L., Holmes, K., 2000. Modeling soillandscape and ecosystem properties using terrain attributes. Soil Sci. Soc. Am. J. 64, 20462056.

Grimm, E.C., 1983. Chronology and Dynamics of Vegetation Change in the Prairie-Woodland Region of Southern Minnesota, USA. New Phytol. 93, 311-350.

Grimm, E.C., 1984. Fire and Other Factors Controlling the Big Woods Vegetation of Minnesota in the Mid-19th Century. Ecol. Monogr. 54, 291-311.

Harris, D., Horwáth, W.R., van Kessel, C., 2001. Acid fumigation of soils to remove carbonates prior to total organic carbon or CARBON-13 isotopic analysis. Soil Sci. Soc. Am. J. 65, 1853-1856.

Hobbie, E., Ouimette, A., 2009. Controls of nitrogen isotope patterns in soil profiles. Biogeochem. 95, 355-371. 
872 Hobbs, H., Goebel, J., 1982. Geologic Map of Minnesota: Quaternary Geology. State Map Series 873 S-1. Minnesota Geological Survey, St. Paul.

874 Hughes, R.E., Warren, R., 1989. Evaluation of the economic usefulnesss of earth materials by X875 ray diffraction., In: Hughes, R.E., Bradbury, J.C. (Eds.), Proceedings of the 23rd Forum on Geology of Industrial Minerals, Mineral Notes 102. Illinois State Geological Survey,

878 Jacobs, P.M., Knox, J.C., Mason, J.A., 1997. Preservation and recognition of middle and early 879 Pleistocene loess in the Driftless area, Wisconsin. Quat. Res. 47, 147-154.

880 Jacobs, P.M., Mason, J.A., Hanson, P.R., 2011. Mississippi Valley regional source of loess on 881 the southern Green Bay Lobe land surface, Wisconsin. Quat. Res. 75, 574-583.

882 Jacobs, P.M., Mason, J.A., Hanson, P.R., 2012. Loess mantle spatial variability and soil 883 horizonation, southern Wisconsin, USA. Quat. Intern. 265, 43-53.

884 Konen, M.E., Jacobs, P.M., Burras, C.L., Talaga, B.J., Mason, J.A., 2002. Equations for 885 predicting soil organic carbon using loss-on-ignition for north central US soils. Soil Sci. Soc. Am. J. 66, 1878-1881.

887 Kubiena, W., 1953. The Soils of Europe. Murby, London.

888 Kucera, M., Malmgren, B.A., 1998. Logratio transformation of compositional data--A resolution 889 of the constant sum constraint. Marine Micropaleontology 34, 117-120.

890 Lively, R.S., Bettis, E.A., III, Hallberg, G.R., Hobbs, H., 1987. An exposure of the Sangamon 891

892 Lueth, R.A., 1984. Soil Survey of Houston County, Minnesota. U.S. Department of Agriculture, soil in southeastern Minnesota. Proc. Iowa Acad. Sci. 94, 111-115. 893 Washington, DC. 
Marschner, F., 1974. The original vegetation of Minnesota. Technical Report, USDA Forest Service. North Central Forest Experiment Station, St. Paul, Minnesota.

Mason, J.A., 1992. Loess distribution and soil landscape evolution, southeastern Minnesota, Soil Science. University of Minnesota, St Paul, 408 pp.

Mason, J.A., 1995. Effects of glacial-interglacial climatic change on mass wasting, southeastern Minnesota, Geography. University of Wisconsin-Madison, Madison, Wisconsin, 346 pp.

Mason, J.A., Knox, J.C., 1997. Age of colluvium indicates accelerated late Wisconsinan hillslope erosion in the Upper Mississippi Valley. Geology 25, 267-270.

Mason, J.A., Nater, E.A., 1994. Soil Morphology-Peoria Loess Grain-Size Relationships, Southeastern Minnesota. Soil Sci. Soc. Am. J. 58, 432-439.

Mason, J.A., Nater, E.A., Hobbs, H.C., 1994. Transport direction of Wisconsinan loess in southeastern Minnesota. Quat. Res. 41, 44-51.

Melillo, J., Aber, J., Linkinkins, A., Ricca, A., Fry, B., Nadelhoffer, K., 1989. Carbon and nitrogen changes along the decay continuum: plant litter to soil organic matter. Plant and Soil 115, 189-198.

Miedema, R., Koulechova, I.N., Gerasimova, M.I., 1999. Soil formation in Greyzems in Moscow district: micromorphology, chemistry, clay mineralogy, and particle size distribution. Catena 34, 315-347.

Mikutta, R., Mikutta, C., Kalbitz, K., Scheel, T., Kaiser, K., Jahn, R., 2007. Biodegradation of forest floor organic matter bound to minerals via different binding mechanisms. Geochim. Cosmochim. Acta 71, 2569-2590.

Minnesota DNR, 2005. Field Guide to the Native Plant Communities of Minnesota: The Eastern Broadleaf Forest Province. Ecological Land Classification Program, Minnesota County 
Biological Survey, and Natural Heritage and Nongame Research Program. Minnesota Department of Natural Resources, St. Paul.

Moore, D.M., Reynolds, R.C., 1989. X-Ray Diffraction and the Identification and Analysis of Clay Minerals. Oxford University Press, New York.

921

922

923

924

925

926

927

928

929

930

931

932

933

934

935

936

937

938

939

Nadelhoffer, K.J., Fry, B., 1988. Controls on Natural Nitrogen-15 and Carbon-13 Abundances in Forest Soil Organic Matter. Soil Sci. Soc. Am. J. 52, 1633-1640.

Nelson, D., Hu, F., 2008. Patterns and drivers of Holocene vegetational change near the prairieforest ecotone in Minnesota: revisiting McAndrews' transect. New Phytol. 179, 449-459.

Neustruev, S., 1927. Genesis of soils, Russian Pedological Investigations. Academy of Sciences of the USSR, Leningrad.

Oades, J.M., 1988. The retention of organic matter in soils. Biogeochemistry 5, 35-70.

O'Leary, M.H., 1988. Carbon isotopes in photosynthesis. BioScience 38, 328-336.

Ramnarine, R., Voroney, R.P., Wagner-Riddle, C., Dunfield, K.E., 2011. Carbonate removal by acid fumigation for measuring the $\delta^{13} \mathrm{C}$ of soil organic carbon. Can. J. Soil Sci. 91, 247-250.

Sage, R.F., Christin, P.-A., Edwards, E.J., 2011. The C4 lineages of planet Earth. J. Experimental Botany 62, 3155-3169.

Schaetzl, R.J., 1991. Factors Affecting the Formation of Dark, Thick Epipedons beneath Forest Vegetation, Michigan, USA. J. Soil Sci. 42, 501-512.

Scharpenseel, H.W., 1971. Radicarbon dating of soils_-problems, troubles, hopes, In: Yaalon, D.H. (Ed.), Paleopedology_Origin, Nature, and Dating of Paleosols, International Society of Soil Science and Israel Univ. Press., Jerusalem, pp. 77-87.

Schimel, D., Stillwell, M.A., Woodmansee, R.G., 1985. Biogeochemistry of C, N, and P in a soil catena of the shortgrass steppe. Ecology 66, 276-282. 
940

941

942

943

944

945

946

947

948

949

950

951

952

953

954

955

956

957

958

959

960

961

Schoeneberger, P., Wysocki, D., Benham, E., Broderson, W., 2002. Field book for describing and sampling soils, Version 2.0. Natural Resource Conservation Service, Nation Soil Survey Center, Lincoln, Nebraska.

Schreier, H., Lavkulich, L., 1985. Rendzona-type soils in the Ogilvie Mountains, Yukon Territory. Soil Sci. 139, 2-12.

Severson, R., Arneman, H., 1973. Soil characteristics of the forest-prairie ecotone in northwestern Minnesota. Soil Sci. Soc. Am. Proc. 37, 593-599.

Shuman, B., Henderson, A., Plank, C., Stefanova, I., Ziegler, S., 2009. Woodland-to-forest transition during prolonged drought in Minnesota after ca. AD 1300. Ecology 90, 27922807.

Team, R.D.C., 2008. R: A language and environment for statistical computing. R Foundation for Statistical Computing, Vienna, Austria.

Teeri, J.A., Stowe, L.G., 1976. Climatic patterns and the distribution of C4 grasses in North America. Oecologia 23, 1-12.

Ugolini, F., Tedrow, J., 1963. Soils of the Brooks Range, Alaska: 3. Rendzina of the Arctic. Soil Sci. 96, 121-127.

Umbanhowar, C., Jr, 2004. Interaction of fire, climate and vegetation change at a large landscape scale in the Big Woods of Minnesota, USA. Holocene 14, 661-676.

von Lützow, M., Kogel-Knabner, I., Ludwig, B., Matzner, E., Flessa, H., Ekschmitt, K., Guggenberger, G., Marschner, B., Kalbitz, K., 2006. Stabilization mechanisms of organic matter in temperate soils: Mechanisms and their relevance under different soil conditions—a review. Eur. J. Soil Science 57, 426-445. 
von Lützow, M., Kogel-Knabner, I., Ekschmitt, K., Matzner, E., Guggenberger, G., Marschner, B., Flessa, H., 2008. Stabilization mechanisms of organic matter in four temperate soils: Development and application of a conceptual model. Journal of Plant Nutrition and Soil Science-Zeitschrift Fur Pflanzenernahrung Und Bodenkunde 171, 111-124.

Wang, Y., Amundson, R., Trumbore, S., 1996. Radiocarbon dating of soil organic matter. Quat. Res. 45, 282-288.

Wang, Y., Cerling, T., Effland, W.R., 1993. Stable isotope ratios of soil carbonate and soil organic matter and indicators of forest invasion of prairie near Ames, Iowa. Oecologia 95, 365-369.

Webb, T., III, Cushing, E., Wright, H.E., Jr., 1983. Holocene changes in the vegetation of the Midwest, In: Wright, H.E., Jr. (Ed.), Late-Quaternary environments of the United States, Vol. 2. The Holocene. University of Minnesota Press, Minneapolis, MN, pp. 142-165.

Wedin, D.A., Tieszen, L.L., Dewey, B., Pastor, J., 1995. Carbon isotope dynamics during grass decomposition and soil organic matter formation. Ecology, 1383-1392.

White, E.M., Riecken, F.F., 1955. Brunizem-Gray Brown Podzolic soil biosequences. Soil Sci. Soc. Am. Proc. 19, 504-509.

Williams, J., Shuman, B., Bartlein, P.J., 2009. Rapid responses of the prairie-forest ecotone to early Holocene aridity in mid-continental North America. Global and Planetary Change 66, 195-207.

Wynn, J.G., Bird, M.I., Wong, V.N., 2005. Rayleigh distillation and the depth profile of 13 C/12 C ratios of soil organic carbon from soils of disparate texture in Iron Range National Park, Far North Queensland, Australia. Geochim. Cosmochim. Acta 69, 1961-1973. 
984 Wynn, J.G., Harden, J.W., Fries, T.L., 2006. Stable carbon isotope depth profiles and soil

985

986

987

988

989

990

991

992

993

994

995

996

997

998

999

1000

1001

1002

1003

1004 1005 data.

organic carbon dynamics in the lower Mississippi Basin. Geoderma 131, 89-109.

Yoo, K., Amundson, R., Heimsath, A.M., Dietrich, W.E., 2006. Spatial patterns of soil organic carbon on hillslopes: Integrating geomorphic processes and the biological C cycle. Geoderma 130, 47-65.

\section{Figure Captions}

Figure 1. a. Vegetation of Minnesota and Wisconsin at the time of $19^{\text {th }}$ century public land surveys (Marschner, 1974; Finley, 1976). White box is study area. b. Topography of the study area (based on US Geological Survey 30-m DEM) with study site locations. Sites in italics are individual ridgetop profiles in thick loess, at other sites, multiple soils were sampled on hillslopes.

Figure 2. Schematic view of typical hillslope stratigraphy in the study area, showing landscape position of Dc and Sm lithofacies and other depositional units (Mason, 1995; Mason and Knox, 1997). A and A’ mark upper and lower limits of soil sampling at study sites.

Figure 3. Topography typical of the study area. Darkest shading indicates Mollisols with thick, dark-colored A horizons on steep slopes (Brodale and Lacrescent soils). Intermediate shading indicates Alfisols typically mapped on footslopes just below those Mollisols (Council, Elbaville, Seaton valleys soils). Alfisols also predominate on ridgetops above the Mollisols on steep slopes.

Two study sites are indicated (CAR, SF). Topography from LiDAR-based 3-m DEM, Minnesota Department of Natural Resources. Soils from Natural Resource Conservation Service SSURGO 
1006 Figure 4. Topographic setting of soils sampled at the four hillslope study sites, identified by 1007 number, with symbols indicating which group they fall in. Topography from LiDAR-based 3-m 1008 DEM, Minnesota Department of Natural Resources; contour interval is $5 \mathrm{~m}$.

1009 Figure 5. Photos of soils representing groups and subgroups identified in this study (see Fig. 4 1010 for locations and topographic settings). Soil horizons are labeled; subhorizons are not 1011 distinguished for clarity although they were described and sampled separately. Soils RH-4 and 1012 RH-5 are separated by about $5 \mathrm{~m}$.

1013 Figure 6. Terrain attributes for hillslope soil locations. a. Profile curvature at randomly located 1014 points in Mollisols on steep slopes (Brodale, Lacrescent soils, 31,701 points) and Alfisols on 1015 adjacent lower slopes (Council, Elbaville, Seaton valleys, 31,701 points). b. Profile curvature of 1016 Group 1 soils (17 profiles) and Group 2 soils on hillslopes (9 profiles). c. Plan curvature at 1017 randomly located points in Mollisols and Alfisols (same points as in a). d. Plan curvatiure of 1018 Group 1 and 2 soils.

1019 Figure 7. Organic carbon content versus depth, for individual horizons of Group 1 and Group 2 1020 soils. Lines indicate overall average across all sampled soils, and separate averages for Groups 1 1021 and 2.

1022 Figure 8. Texture, clay mineralogy, pH, and OC content with depth, for six soils representative 1023 of Group 1 and Groups 2A and 2B. Includes the four soils illustrated in Fig. 5 plus a ridgetop soil 1024 in thick loess (AL) and a Group 1 soil under prairie (SF-2). Dashed gray line to right of OC 1025 panel indicates coarse dolomite fragments occupying greater than about 5\% of soil volume; solid 1026 gray line indicates effervescence of fine earth in $10 \% \mathrm{HCl}$. 
1027 Figure 9. Results of principal components analysis. Panels at left show loadings of original 1028 variables on pairs of components. Panels at right plot individual soil horizons by their scores on 1029 pairs of components, with symbols differentiating samples by group and horizon type.

1030 Figure 10. Stable $\mathrm{C}$ and $\mathrm{N}$ isotopic data and C:N ratios for all samples analyzed, except the four 1031 replicate profiles of CAR-7 (see Fig. 11). C:N ratios are based on determinations of total C and $1032 \mathrm{~N}$ at UC-Davis SIF, on the same samples used for isotopic analysis.

1033 Figure 11. a. Relationship between $\delta^{13} \mathrm{C}$ and $\delta^{15} \mathrm{~N}$ in the same horizons, with results of linear 1034 regression analysis, by group. b. C isotope composition with depth for CAR-7 and four replicate 1035 profiles (-R1, -R2, etc.). 
Table 1. Soil profiles used for each type of analysis, by site and morphological group (see Results section for group definitions). Profiles at hillslope sites (CAR, RN, RH, SF) are identified by site-specific numbers; see Fig. 3 for locations of these profiles within each site.

\begin{tabular}{|c|c|c|c|c|c|}
\hline Analysis & CAR (NE-facing, forest) & RN (NW-facing, forest) & RH (NW-facing, forest) & SF (SW-facing, prairie) & $\begin{array}{l}\text { Ridgetop loess sites } \\
\text { (forest) }\end{array}$ \\
\hline $\mathrm{OC}, \mathrm{pH}$ & $\begin{array}{l}\text { Group 1: 4, 5, 6, } 7 \\
\text { Group 2A: 1, 2, } 9 \\
\text { Group 2B: } 3\end{array}$ & $\begin{array}{l}\text { Group 1: } 3 \\
\text { Group 2A: } 1 \\
\text { Group 2B: 2, 4, } 5\end{array}$ & $\begin{array}{l}\text { Group 1: 1, 2, 3, 4, } 6 \\
\text { Group 2B: } 5\end{array}$ & Group 1: 1, 2, 3, 4, 5, 6 & $\begin{array}{l}\text { Group 2A: Albert, CAR- } \\
\text { South, VR }\end{array}$ \\
\hline $\begin{array}{l}\text { Clay mineral., } \\
\text { PCA, linear } \\
\text { modeling } \\
\end{array}$ & $\begin{array}{l}\text { Group 1: 4, 5, 6, } 7 \\
\text { Group 2A: 1, 2, } 9 \\
\text { Group 2B: } 3\end{array}$ & $\begin{array}{l}\text { Group 2A: } 1 \\
\text { Group 2B: 2, } 5\end{array}$ & $\begin{array}{l}\text { Group 1: 2, } 4 \\
\text { Group 2B: } 5\end{array}$ & Group 1: 2, 3, 6 & $\begin{array}{l}\text { Group 2A: Albert, VR } \\
\text { (VR for clay mineralogy } \\
\text { only) }\end{array}$ \\
\hline $\mathrm{C}$ and $\mathrm{N}$ isotopes & $\begin{array}{l}\text { Group 1: 5, } 7 \text { (+ } 3 \\
\text { replicates), } 12 \\
\text { Group 2A: 1, } 2 \\
\text { Group 2B: } 3\end{array}$ & $\begin{array}{l}\text { Group 1: } 3 \\
\text { Group 2A: } 1\end{array}$ & $\begin{array}{l}\text { Group 1: 2, } 4 \\
\text { Group 2B: } 5\end{array}$ & Group 1: 1, 2, 5 & \\
\hline
\end{tabular}


Table 2. Results of principal components analysis

Variables: Diff OC, pH, \% sand, \% silt, \% clay, \% smectite, \% vermiculite, \% illite, \% kaolinite + chlorite (variables in italics were logratio transformed before analysis)

\begin{tabular}{lrrr} 
Importance of components & & & \\
\hline & Comp. 1 & Comp. 2 & Comp. 3 \\
\hline Standard Deviation & 1.870 & 1.539 & 1.383 \\
Proportion of Variance & 0.389 & 0.263 & 0.212 \\
Cumulative Proportion & 0.389 & 0.652 & 0.865 \\
\hline
\end{tabular}

\begin{tabular}{lrrr} 
Loadings & & & \\
\hline & Comp. 1 & Comp. 2 & Comp. 3 \\
\hline Diff OC & -0.289 & 0.242 & -0.372 \\
pH & 0.144 & 0.224 & -0.589 \\
sand & 0.459 & -0.228 & -0.257 \\
silt & -0.305 & 0.300 & 0.384 \\
clay & -0.486 & 0.106 & \\
smectite & -0.353 & -0.261 & -0.404 \\
vermiculite & -0.109 & -0.558 & 0.229 \\
illite & 0.164 & 0.593 & \\
kaolinite+chlorite & 0.439 & & 0.275 \\
\hline
\end{tabular}

Table 3. Linear models predicting Diff OC. For all models, the coefficients and intercept are all significantly different from zero $(p<0.001)$, except for the coefficients for $\%$ smectite and $\%$ vermiculite in the last two equations, which are not significantly different from zero. AIC is Akaike Information Criterion; $\mathrm{n}=111$.

\begin{tabular}{llll}
\hline Model & Overall F-statistic $(\boldsymbol{p})$ & Adj. $^{\mathbf{2}}$ & AIC \\
\hline Diff OC $=0.781-0.018$ Sand & $32.18(<0.001)$ & 0.23 & 257 \\
Diff OC $=-0.951+0.052$ Clay & $51.41(<0.001)$ & 0.31 & 242 \\
Diff OC $=-1.794-0.025$ Sand $+0.426 \mathrm{pH}$ & $53.73(<0.001)$ & 0.49 & 211 \\
Diff OC $=-3.850+0.064$ Clay $+0.398 \mathrm{pH}$ & $70.82(<0.001)$ & 0.56 & 194 \\
Diff OC $=-3.861+0.062$ Clay $+0.391 \mathrm{pH}-0.003$ Smect & $46.96(<0.001)$ & 0.56 & 196 \\
Diff OC $=-3.411+0.063$ Clay $+0.365 \mathrm{pH}-0.010$ Vermic & $47.62(<0.001)$ & 0.56 & 195 \\
\hline
\end{tabular}

Table 4. Radiocarbon ages of bulk soil organic matter, CAR7 soil profile

\begin{tabular}{llrr}
\hline Depth (cm) & Lab Number & Age $\left({ }^{14} \mathbf{C}\right.$ yr BP $)$ & $\boldsymbol{\delta}^{\mathbf{1 3} \mathbf{C}}$ \\
\hline $0-5$ & OS- 85327 & {$[110 \%$ modern $]$} & 25.05 \\
$20-25$ & OS- 85328 & $415 \pm 25$ & 19.14 \\
$42-47$ & OS-85342 & $895 \pm 30$ & 17.41 \\
\hline
\end{tabular}


Table 5. Vegetation recorded near section and quarter section corners, located on Mollisols likely to have formed in the DC lithofacies, Houston County, Minnesota, public land survey of 1854 (calculated from dataset of Almendinger, 1990).

\begin{tabular}{lrr} 
Vegetation & $\begin{array}{c}\text { Corners with NW, } \\
\text { N, NE Aspects }\end{array}$ & $\begin{array}{c}\text { Corners with SW, } \\
\text { S, SE Aspect }\end{array}$ \\
\hline Description & $88(50 \%)$ & $64(37 \%)$ \\
Forest & $60(34 \%)$ & $58(33 \%)$ \\
Brattering timber/oaks & $1(<1 \%)$ & $1(<1 \%)$ \\
Oak openings & $5(3 \%)$ & $9(5 \%)$ \\
Grove & $3(2 \%)$ & 0 \\
Oak barrens & 0 & $2(1 \%)$ \\
Prairie & $7(4 \%)$ & $12(7 \%)$ \\
Dry land/Dry ridge & $11(6 \%)$ & $29(17 \%)$ \\
& $175(100 \%)$ & $175(100 \%)$ \\
\hline
\end{tabular}




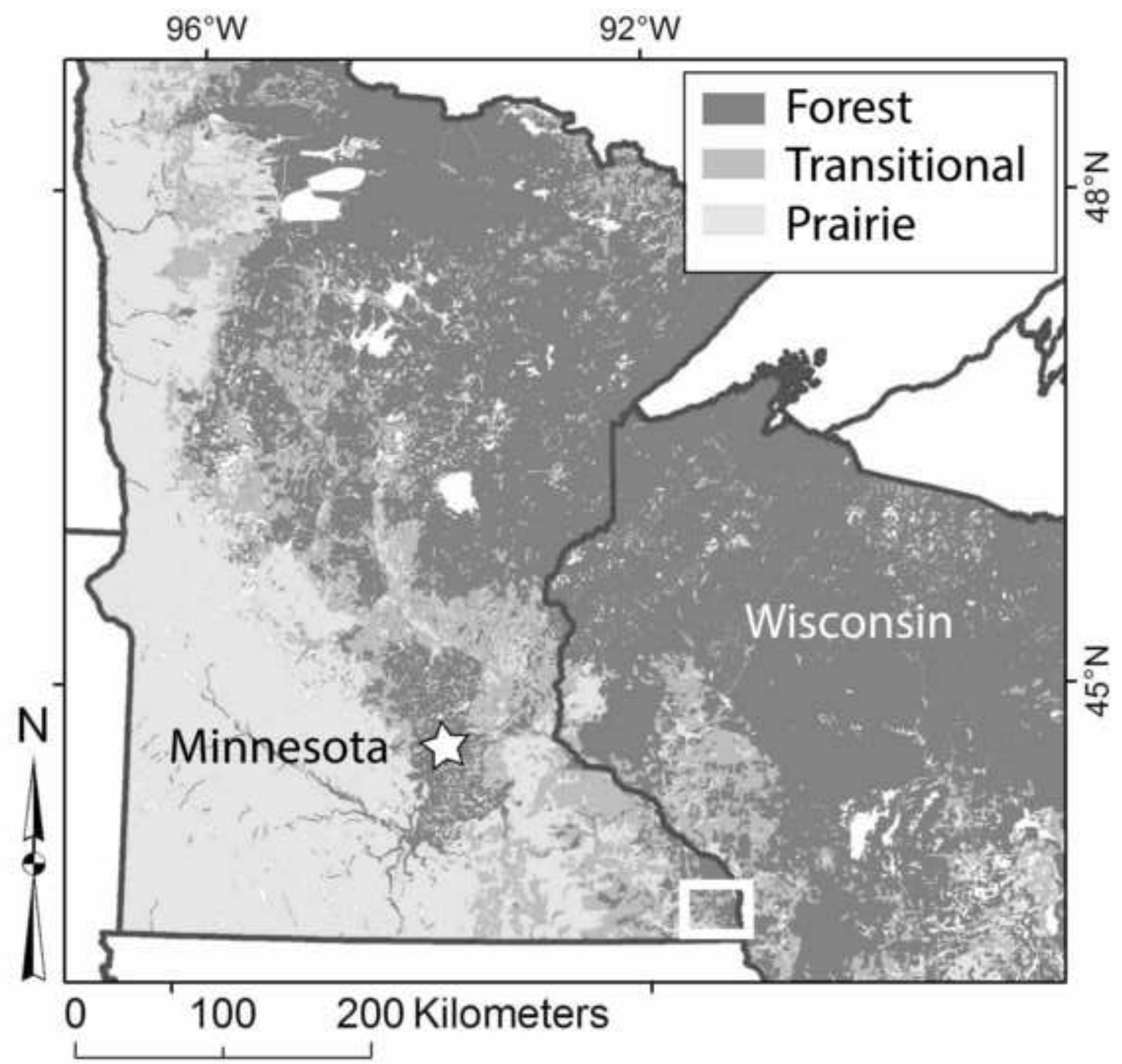




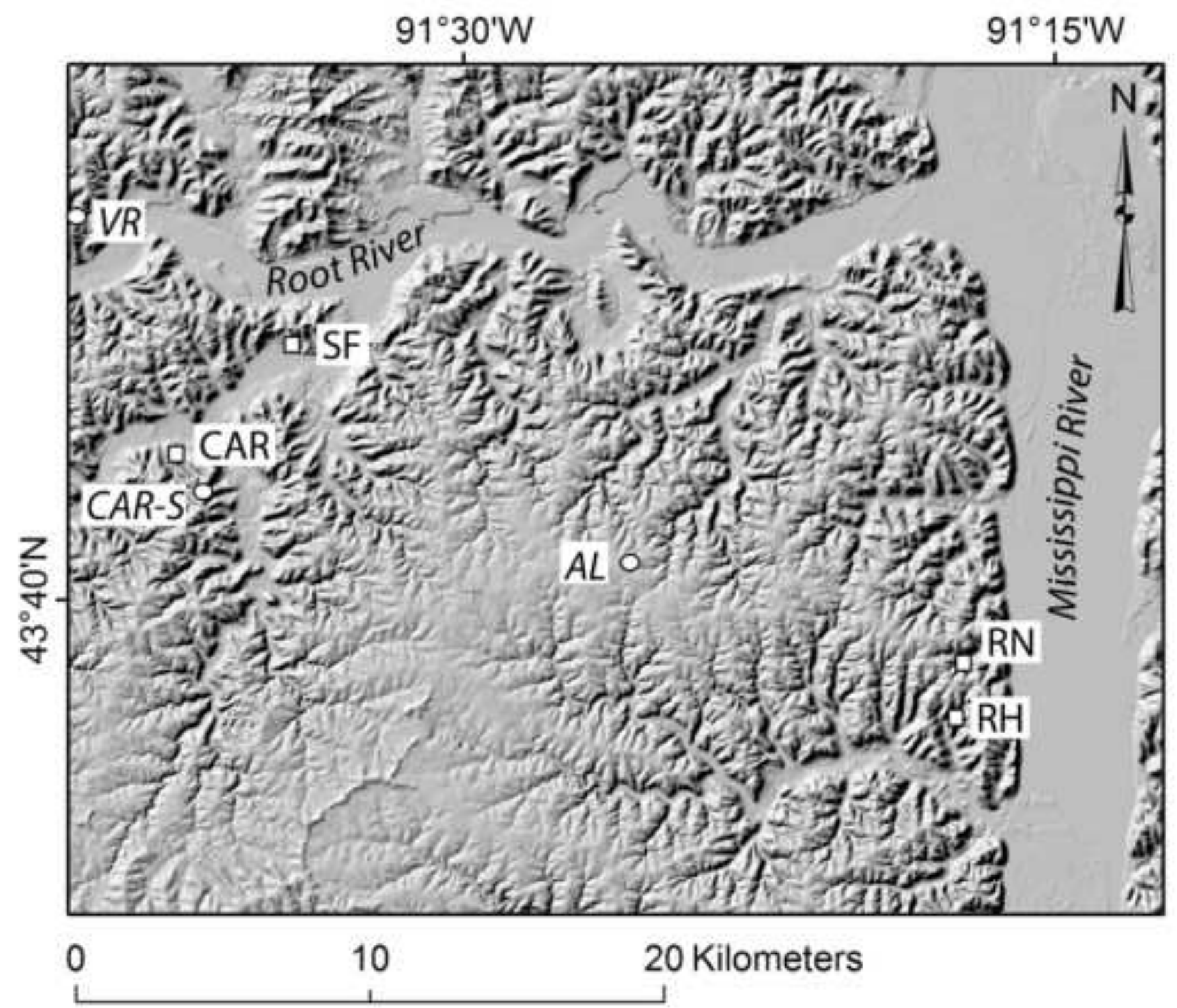




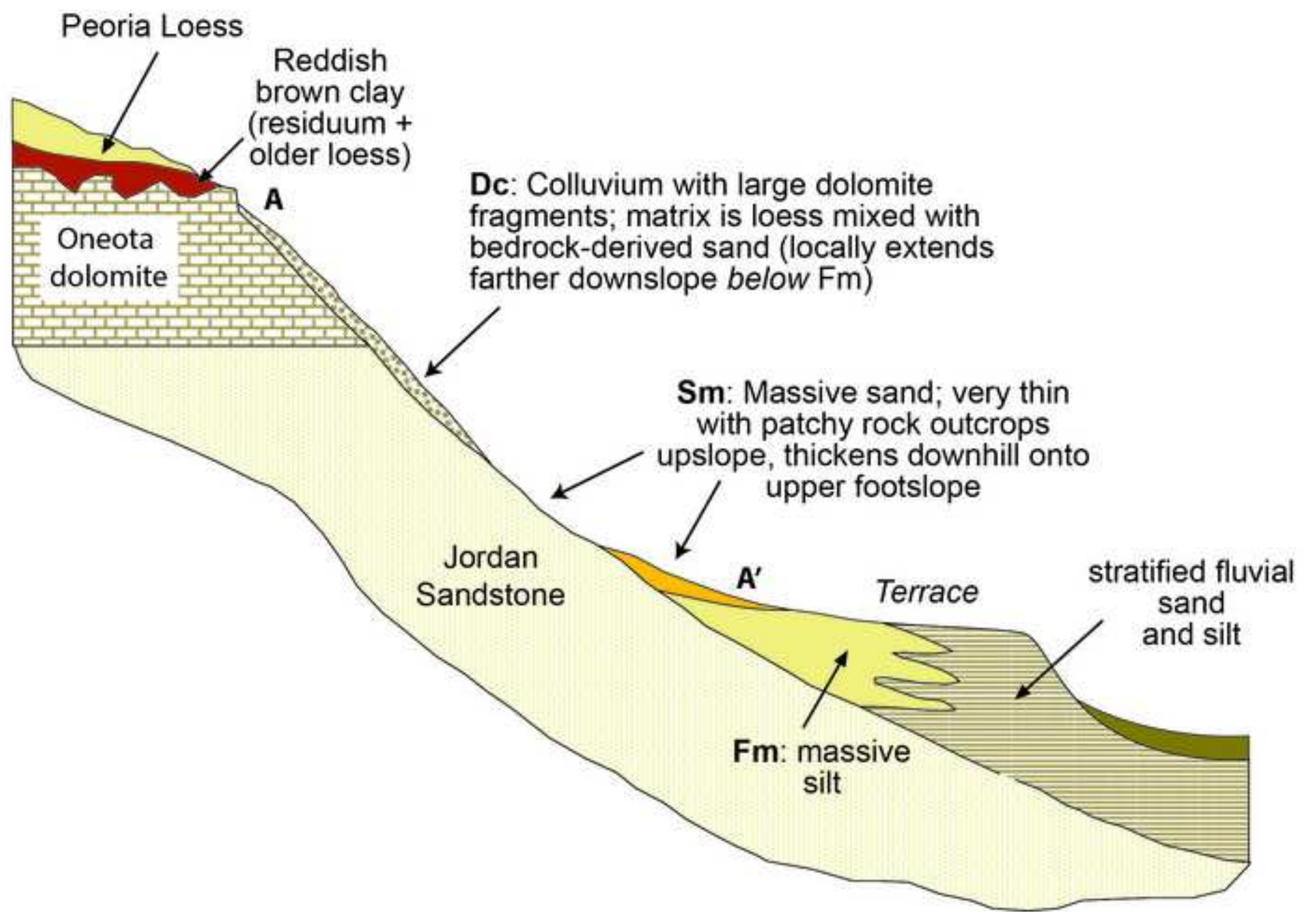




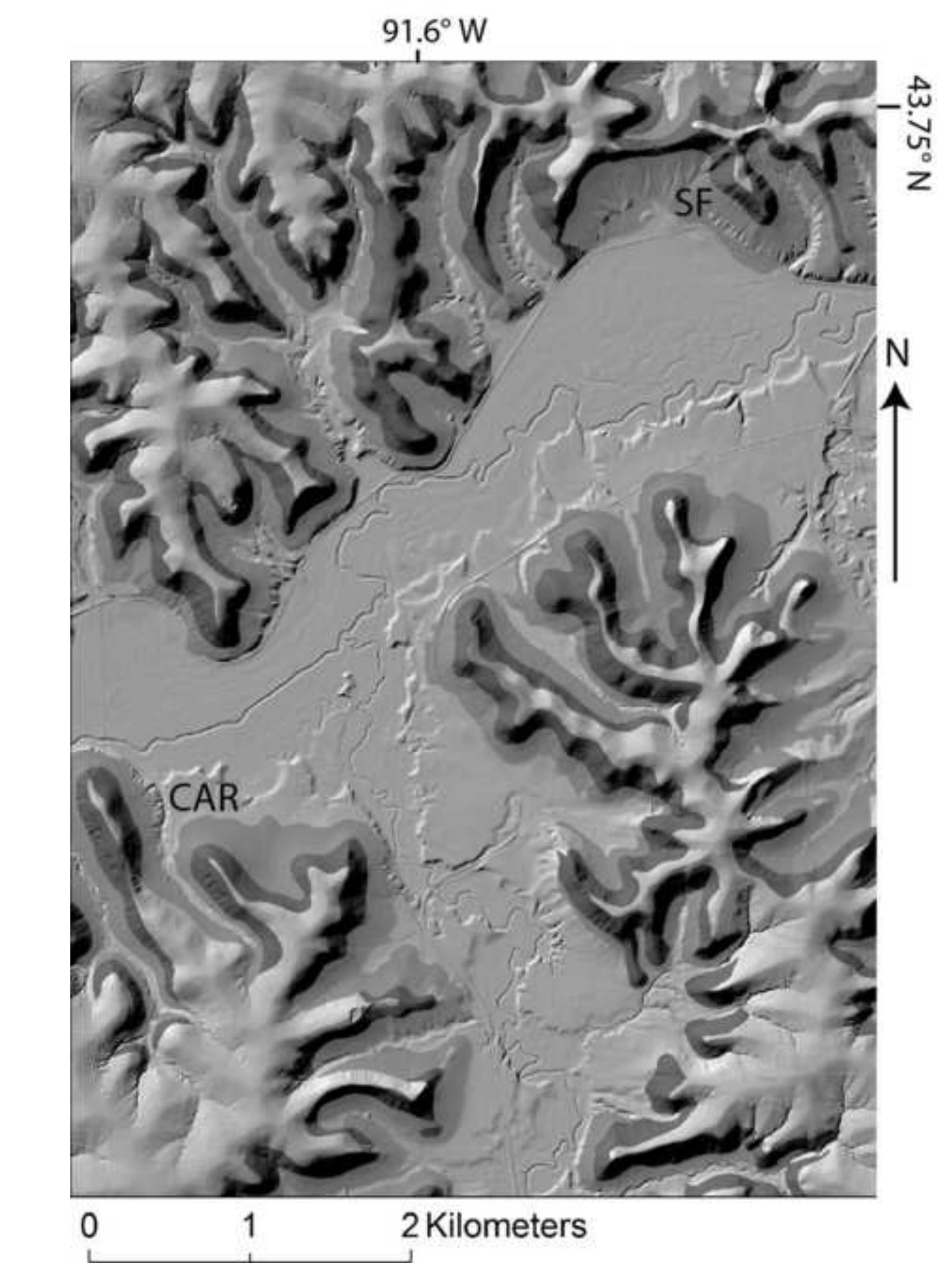

Figure 3

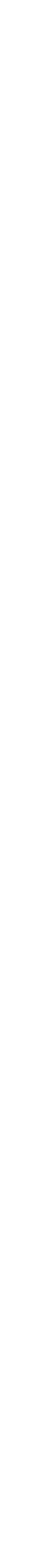

บ

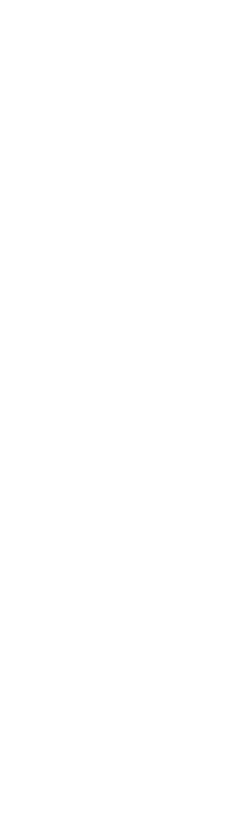



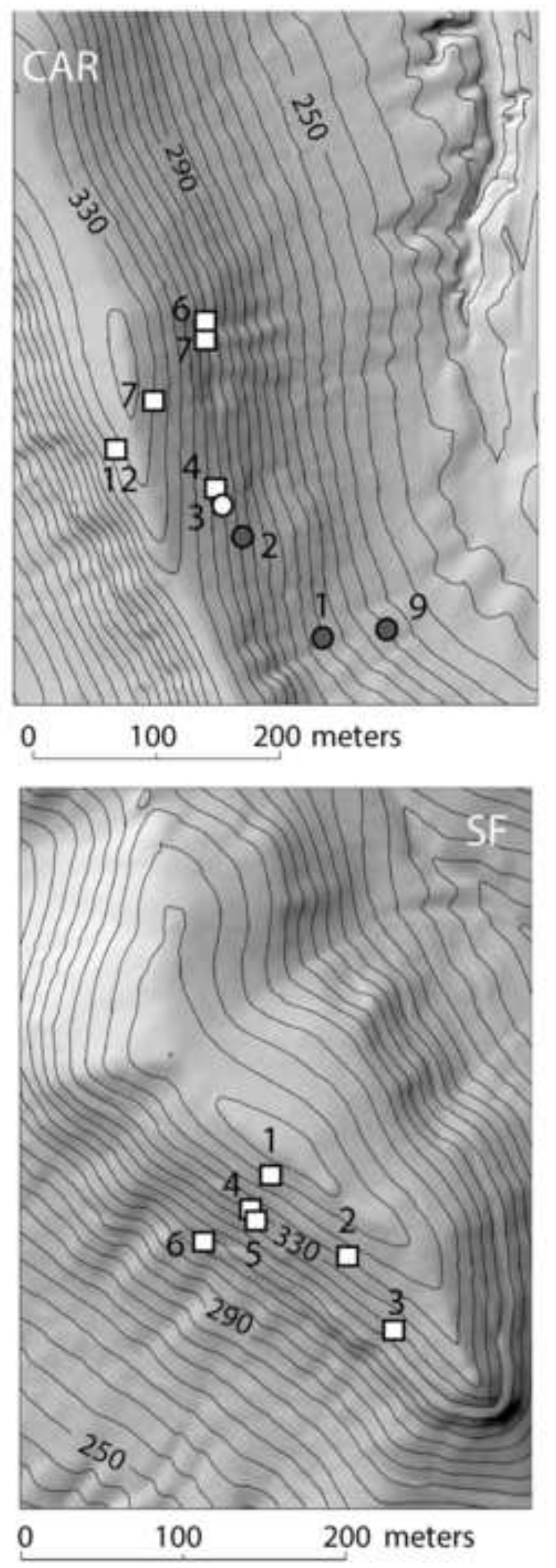
$0 \quad 100 \quad 200$ meters

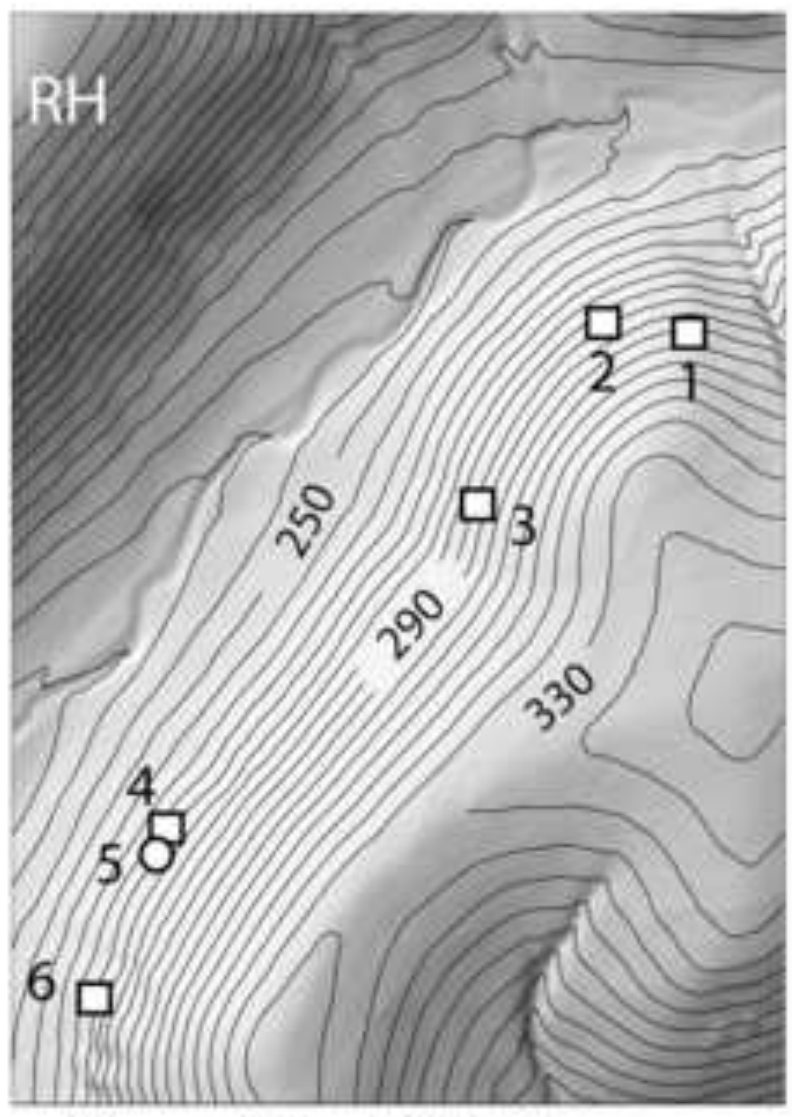

$0 \quad 100 \quad 200$ meters

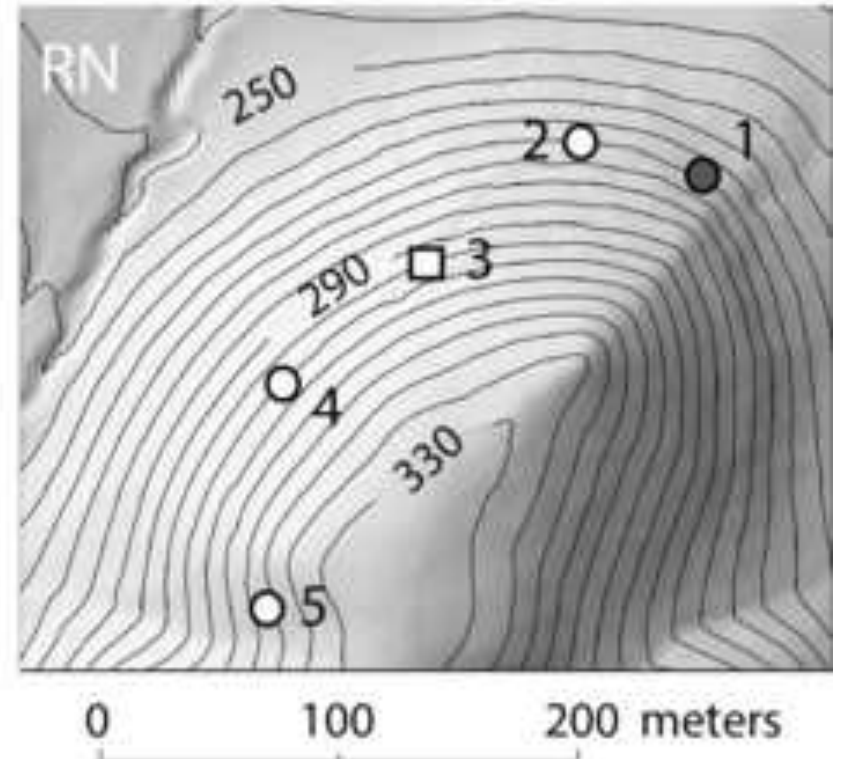

ㅁ Group 1 soils

- Group 2A soils

- Group 2B soils 

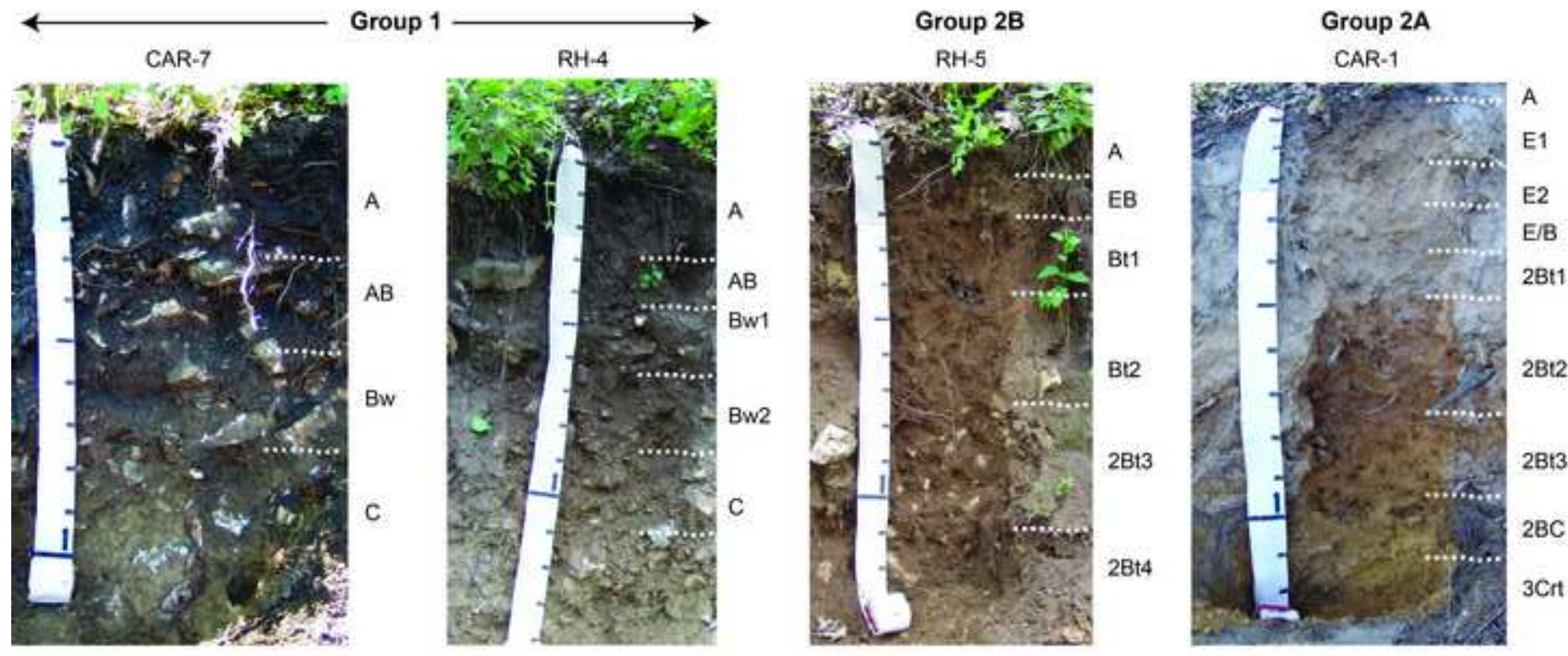

$A$
$E 1$
$E 2$
$E / B$
$2 B t 1$
$2 B t 2$
$2 B t 3$
$2 B C$
$3 C r t$



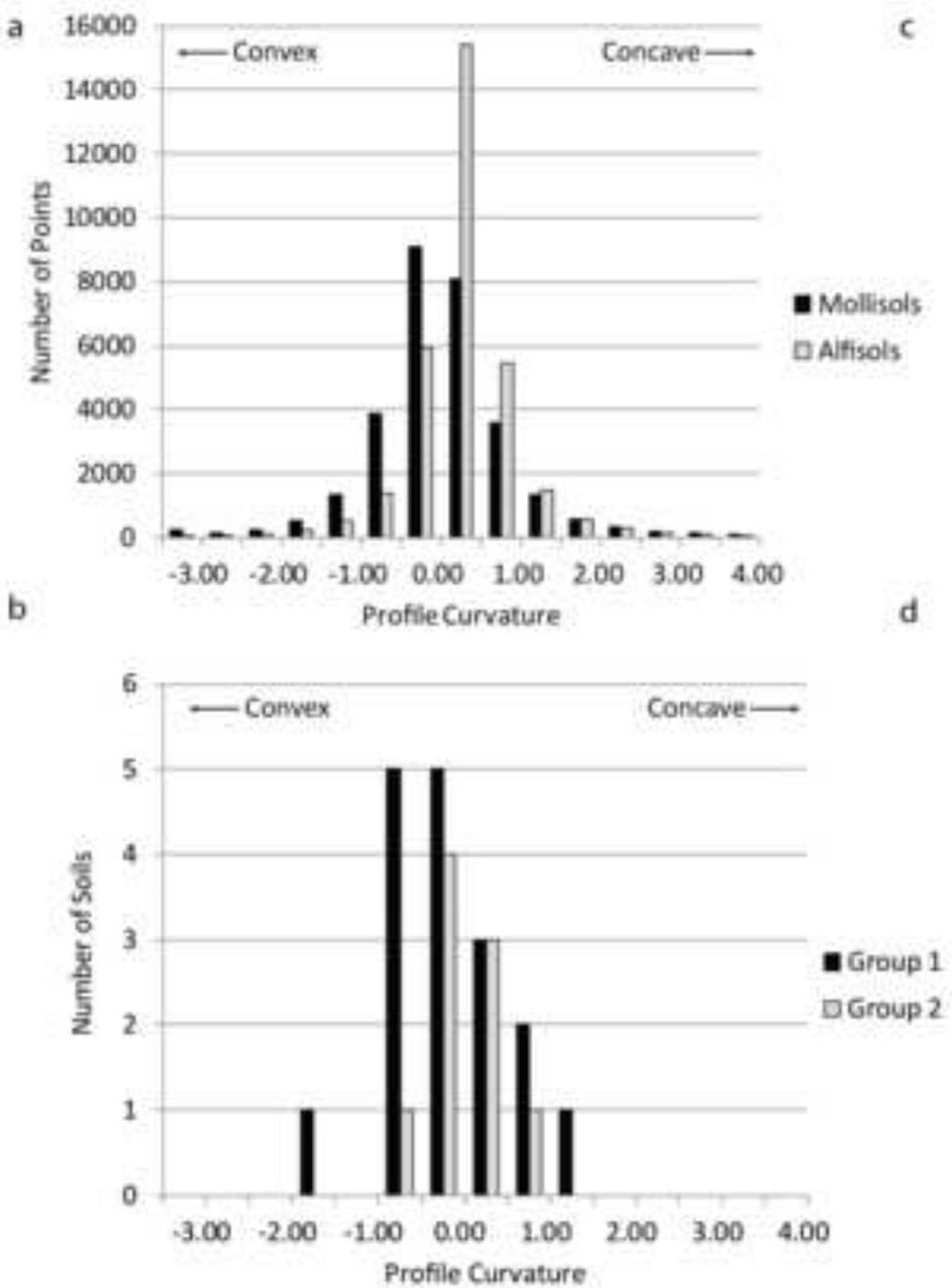
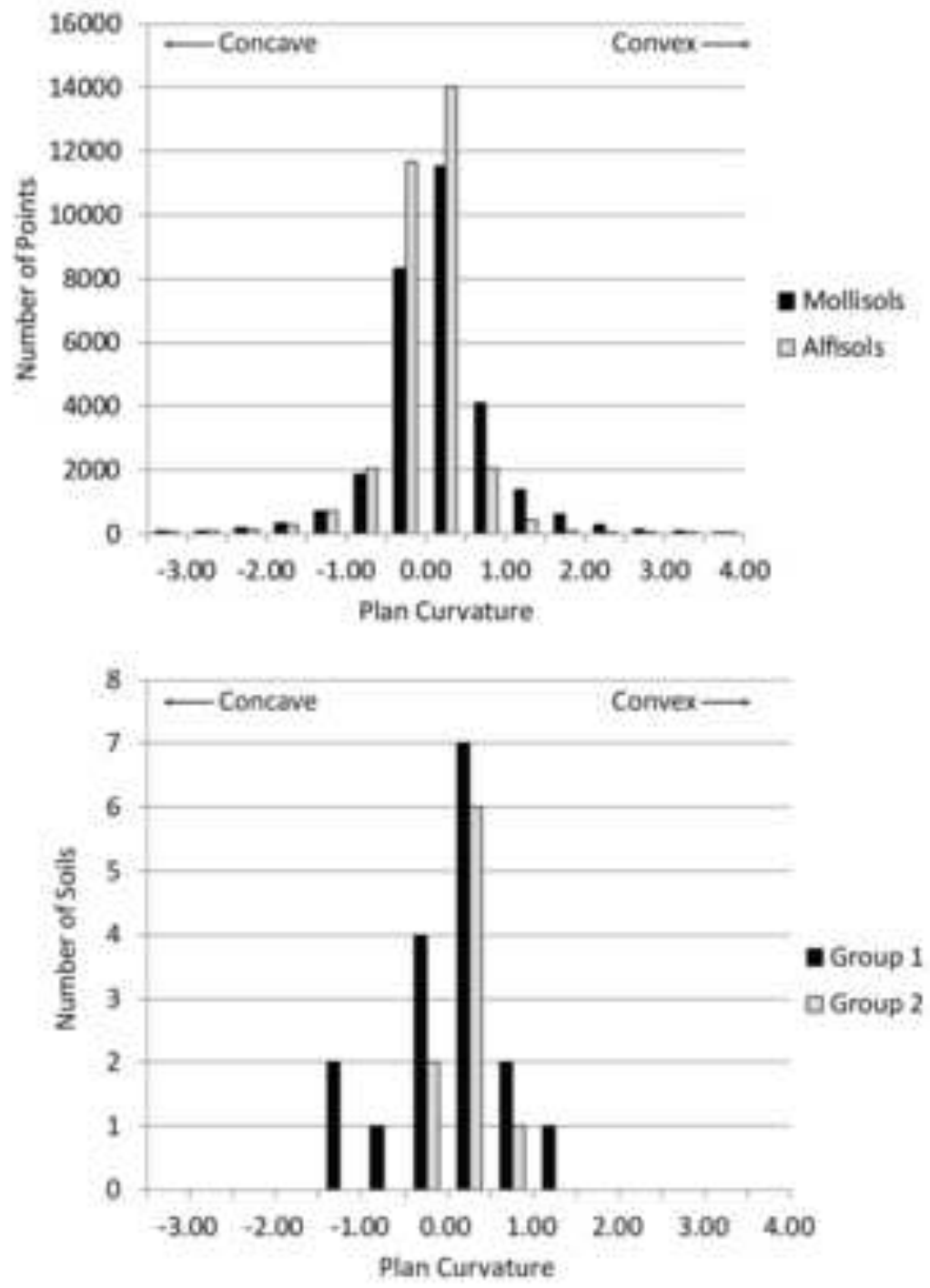


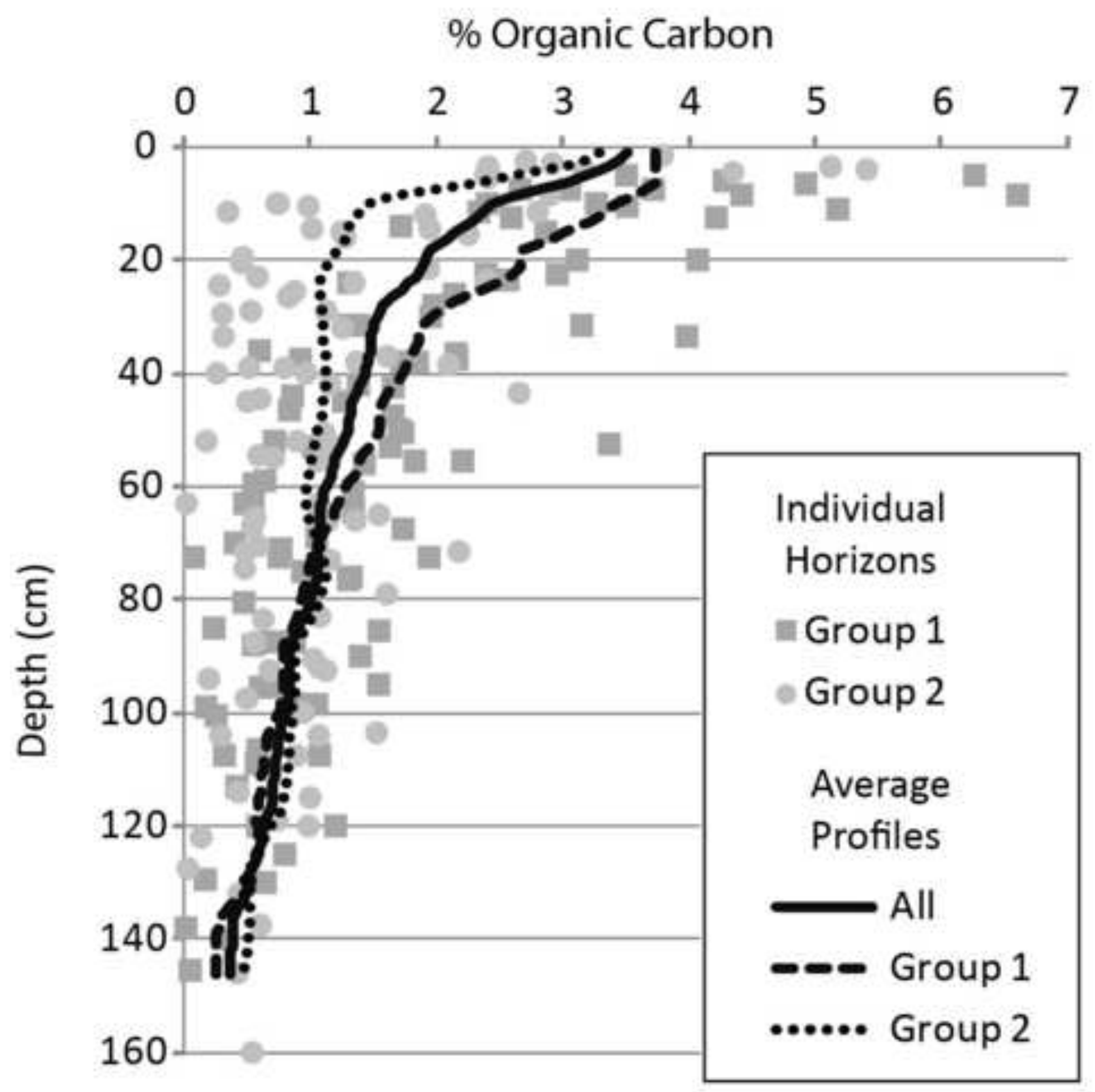


Sand, Silt, and Clay Content

(Cumulative \%)

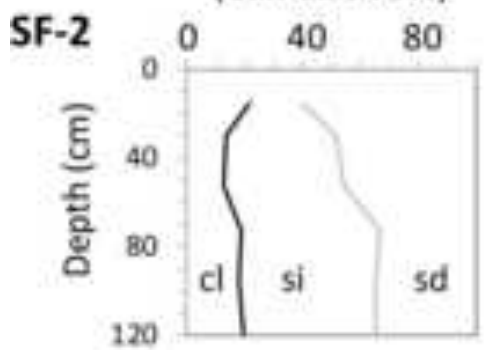

Clay Mineral

Content

(Cumulative \%)
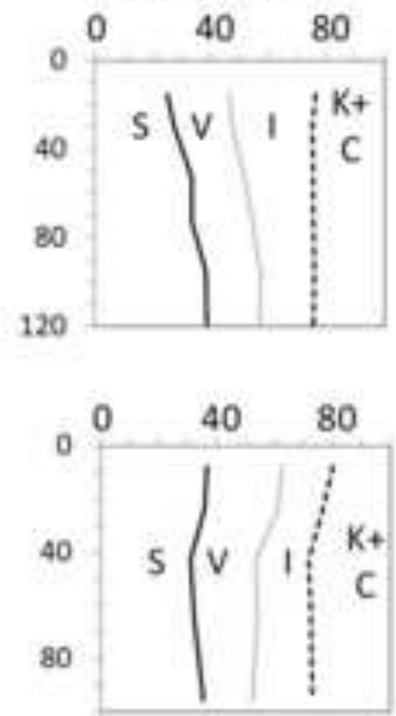
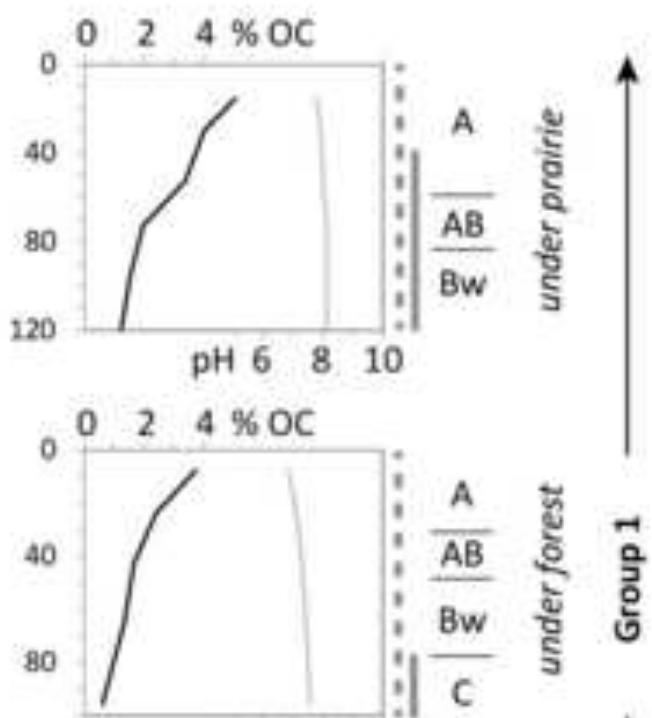

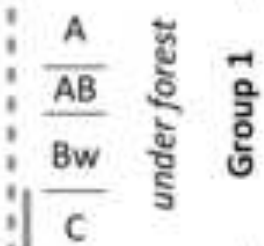

$\begin{array}{llll}\mathrm{pH} & 6 & 8 & 10\end{array}$

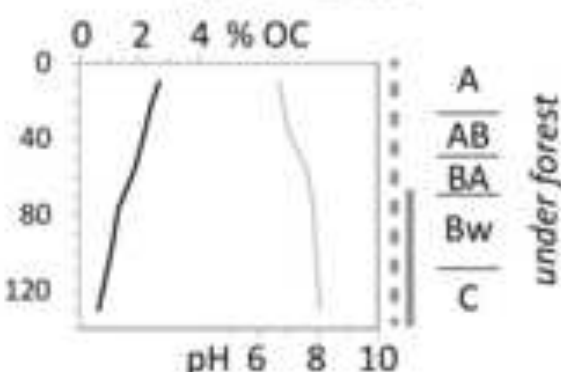

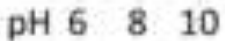
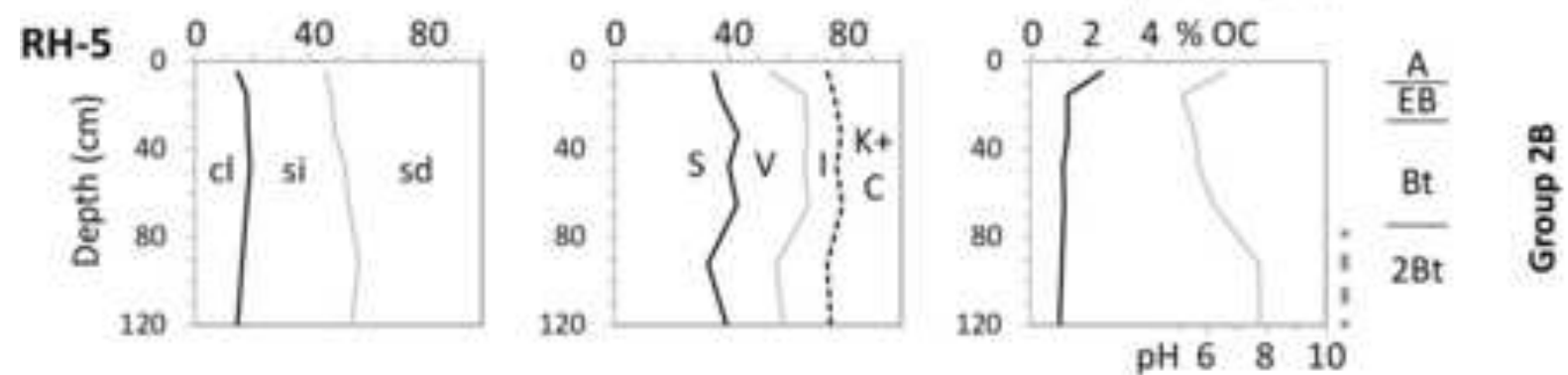

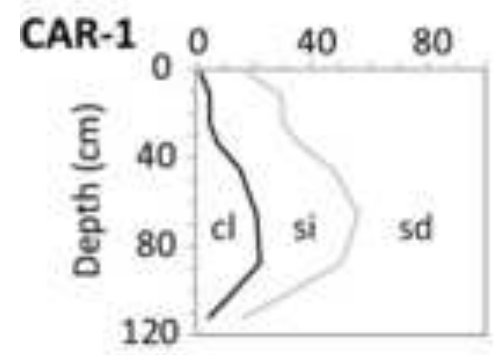

AL

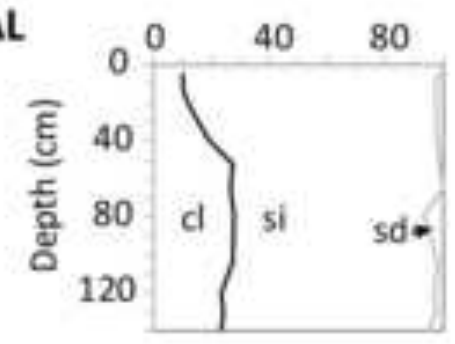

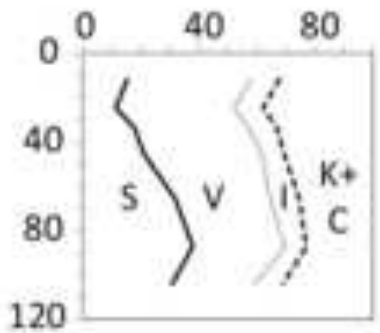
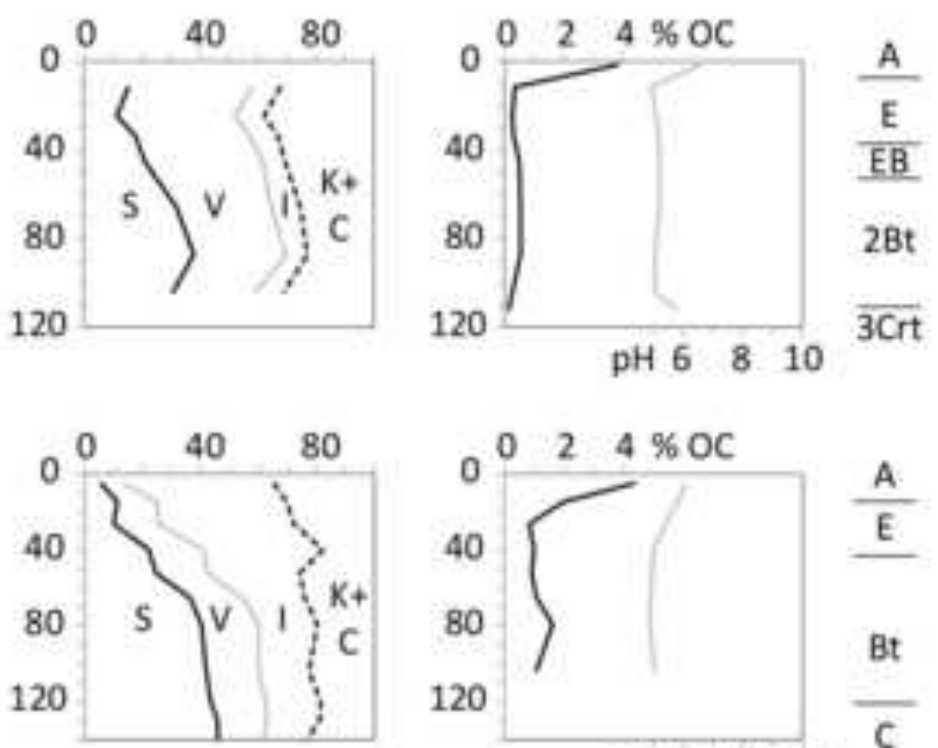

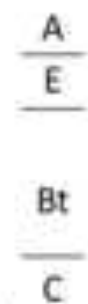

$\begin{array}{llll}\mathrm{pH} & 6 & 8 & 10\end{array}$ 
Figure 9

a

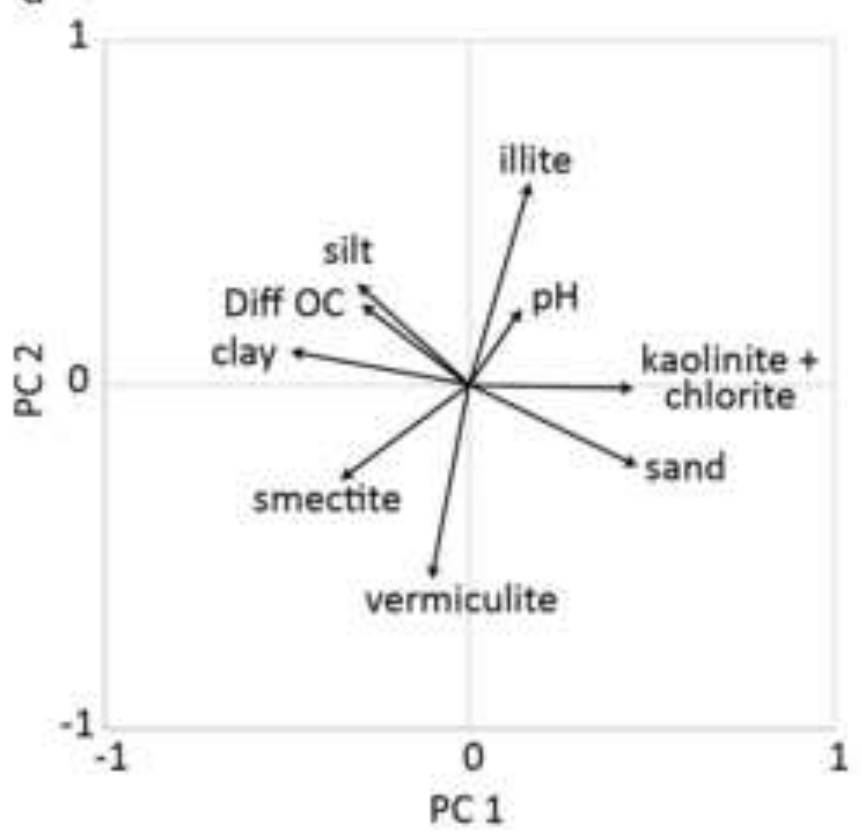

c

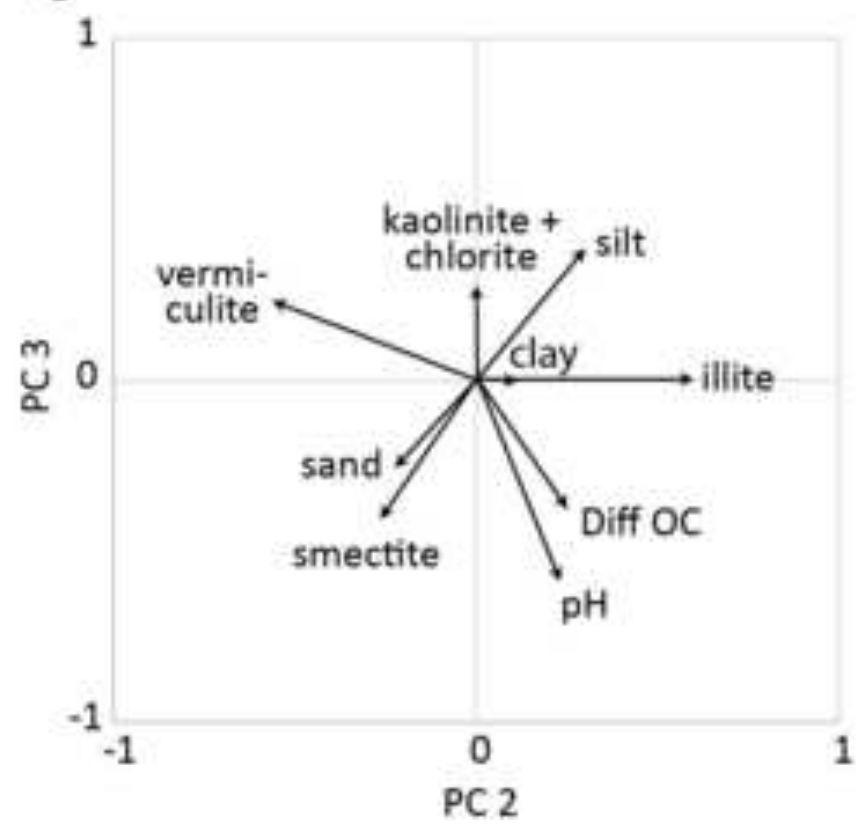

b

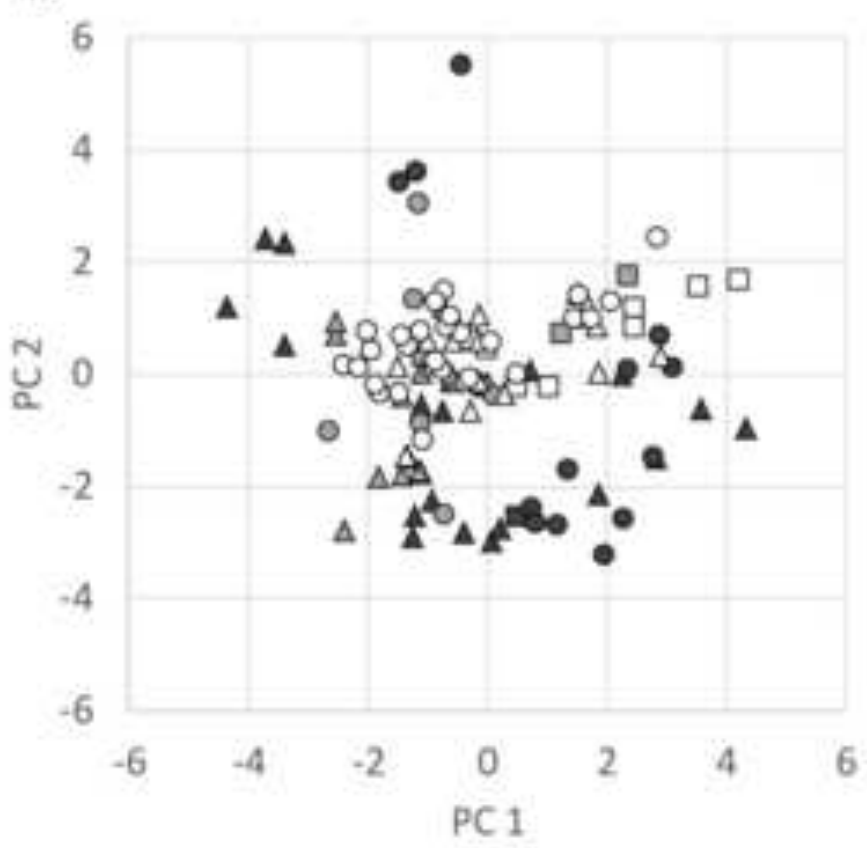

d

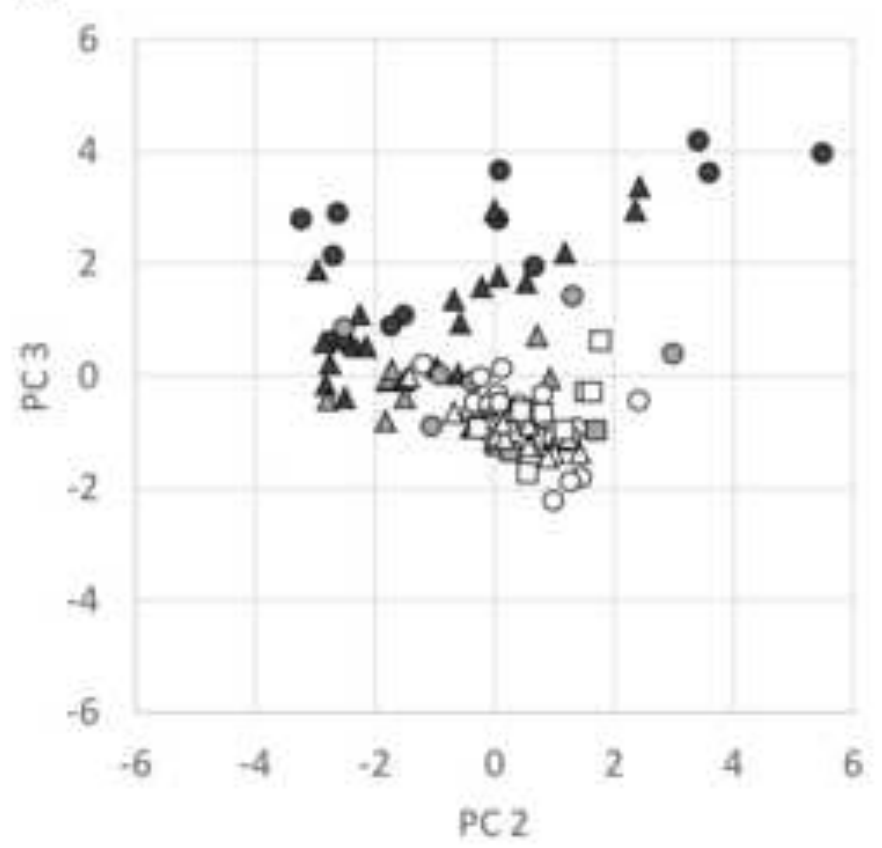

Group 1
$D A, A B$
$\triangle B, B A$
$\square C, B C$

Group 2A

- A, E, EA, BB

$\triangle \mathrm{B}, \mathrm{BE}$

C, BC

Group 2B

- A, E, EA

$\triangle B, B A$

$\square C$ 

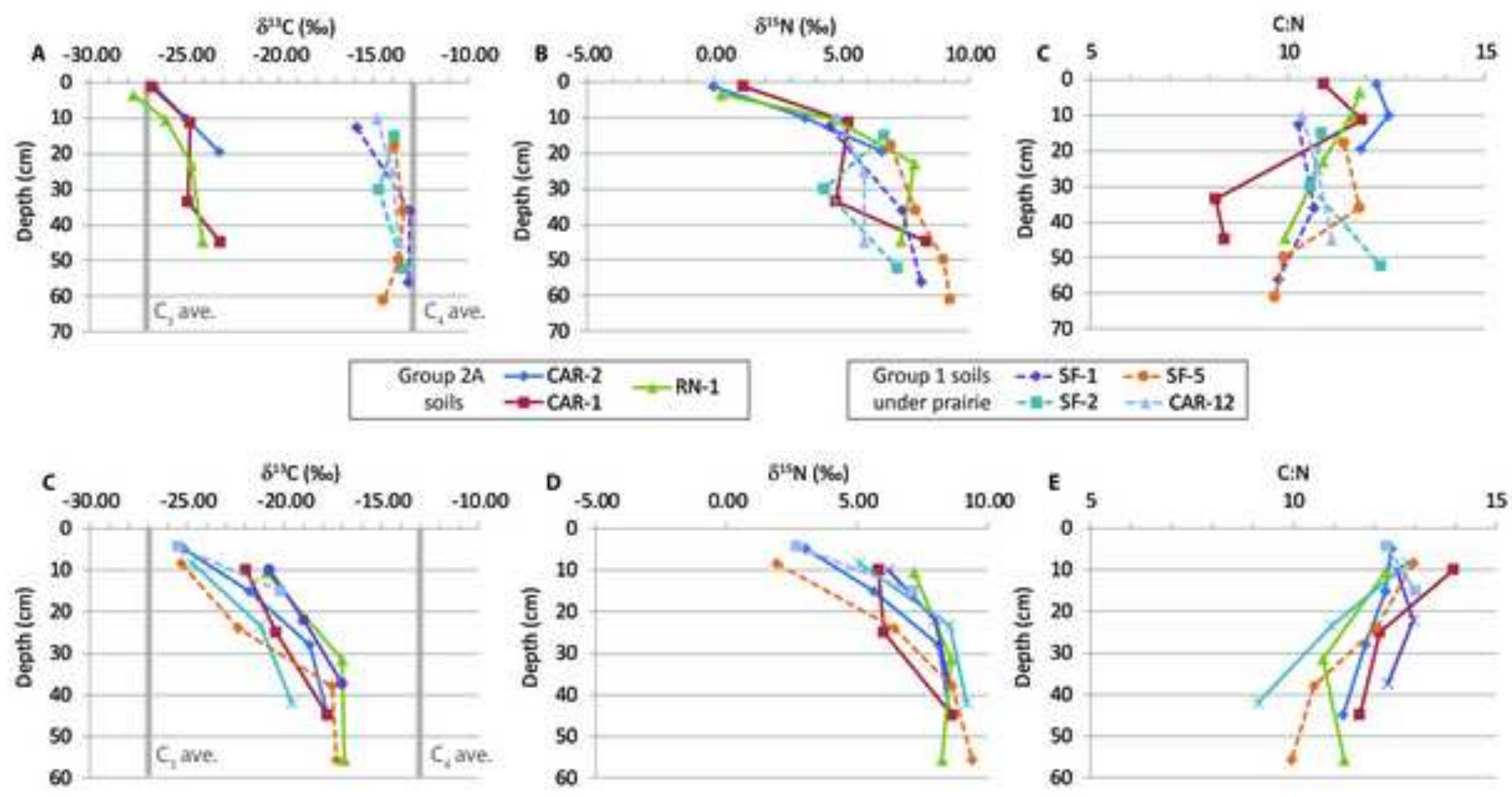

\begin{tabular}{|cc|}
\hline $\begin{array}{c}\text { Group 28 } \\
\text { soils }\end{array}$ & $-0-$ 9H-5 \\
\hline
\end{tabular}

Group 1 soils $\rightarrow$ CAR-5 $\rightarrow$ RH-2

under forest $\rightarrow$-CAR-7 $\rightarrow-\mathrm{RH}_{-}-\mathrm{AN}-3$ 


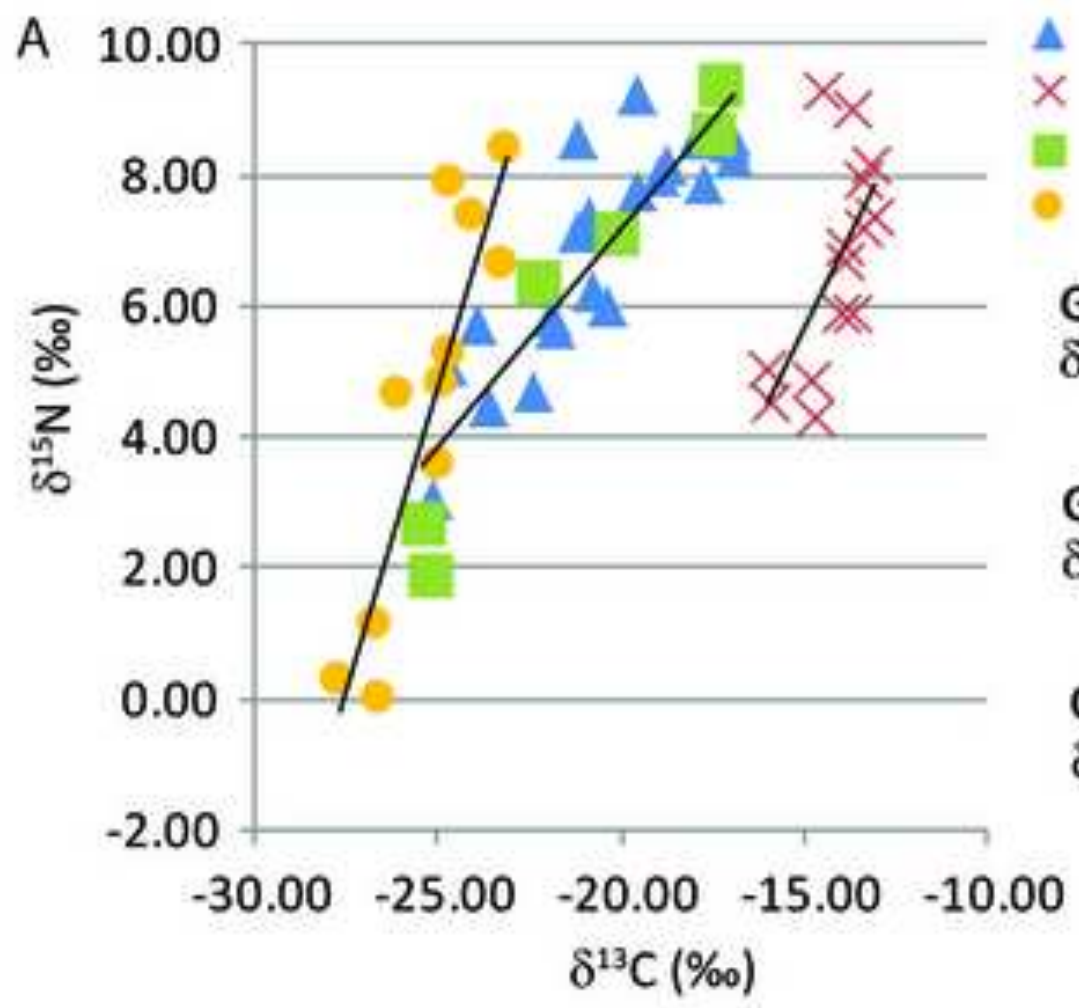

Group 1 (forest)

$\times$ Group 1 (prairie)

Group 2A

Group 2B

Group 2A:

$\delta^{15} \mathrm{~N}=1.81 \delta^{13} \mathrm{C}+50.1$

$$
R^{2}=0.80
$$

Group 1 (prairie):

$\delta^{15} \mathrm{~N}=1.12 \delta^{13} \mathrm{C}+22.5$

$$
R^{2}=0.42
$$

Group 1 (forest) + Group 2B:

$\delta^{15} \mathrm{~N}=0.66 \delta^{13} \mathrm{C}+20.4$ $R^{2}=0.81$

$$
\begin{aligned}
& \begin{array}{lllll}
-30.00 & -25.00 & -20.00 & -15.00 & -10.00
\end{array} \\
& \delta^{13} \mathrm{C}(\%)
\end{aligned}
$$

$\delta^{13} \mathrm{C}(\%)$

$\begin{array}{llllll}\text { B } & -30.00 & -25.00 & -20.00 & -15.00 & -10.00\end{array}$

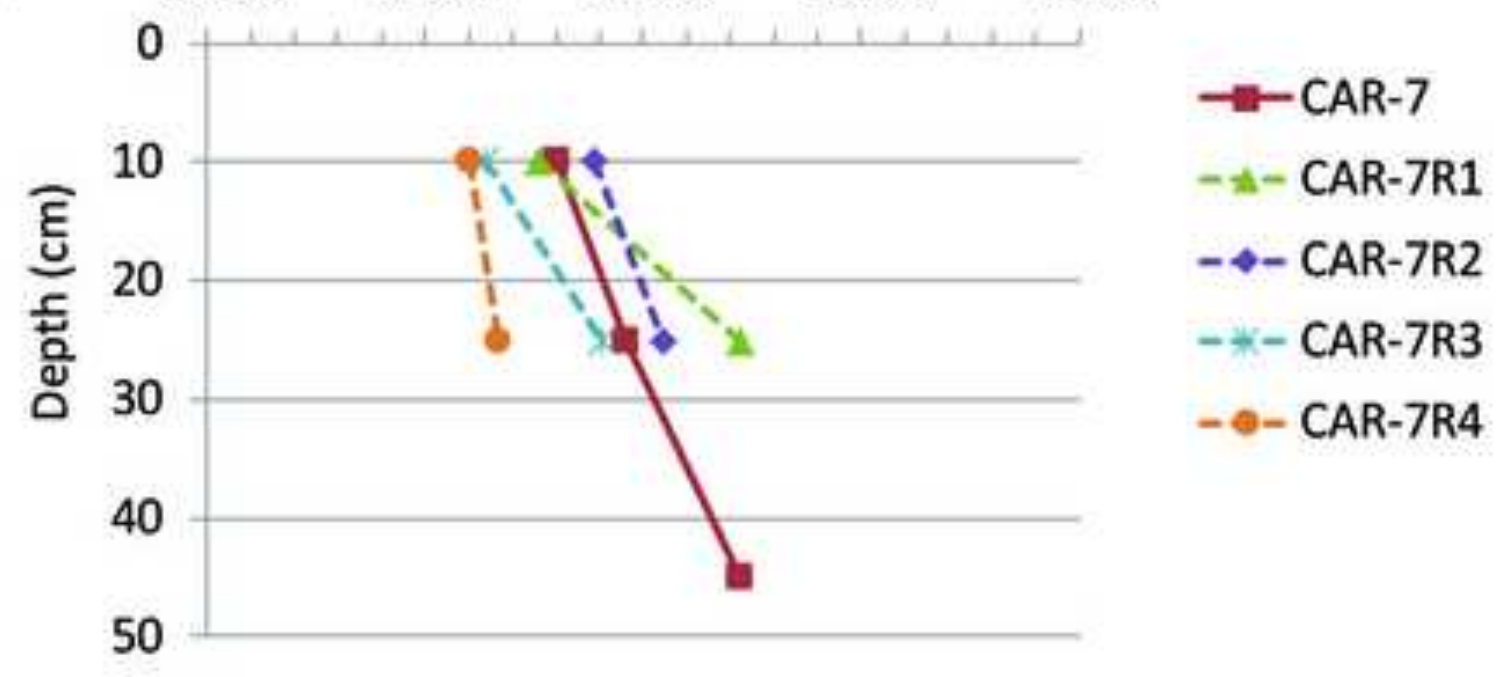

